\title{
Measuring the impact of manganese exposure on children's neurodevelopment: advances and research gaps in biomarker- based approaches
}

Donna J. Coetzee ${ }^{1}$, Patricia M. McGovern ${ }^{2 *}$, Raghavendra Rao ${ }^{3}$, Lisa J. Harnack ${ }^{4}$ Michael K. Georgieff and Irina Stepanov ${ }^{6}$

\begin{abstract}
Background: Children's exposure to manganese (Mn) is a public health concern and consistent policy guidelines for safe levels of Mn exposure is lacking. The complexity of establishing exposure thresholds for $\mathrm{Mn}$ partially relates to its dual role as an essential micronutrient with low levels required for good health, but also as a neurotoxin at high levels. Questions exist about the age-related susceptibility to excess Mn, particularly for children, and how best to measure chronic exposures. To address this concern we conducted a systematic review of studies examining children's exposure to Mn and neurodevelopmental outcomes focused on selection of biomarker-based and environmental measurements of Mn exposure to identify the scientific advances and research gaps.
\end{abstract}

Methods: PubMed and EMBASE databases were searched through March 2016 for studies that were published in English, used a biomarker-based or environmental measurement of Mn exposure, and measured at least one neurological outcome for children aged 0-18 years. Ultimately, thirty-six papers from 13 countries were selected. Study designs were cross-sectional (24), prospective cohorts (9), and case control (3). Neurodevelopmental outcomes were first assessed for Mn exposure in infants (6 papers), toddlers or preschoolers (3 papers) and school-age children (27 papers).

Results: Studies of school-aged children most frequently measured Intelligence Quotient (IQ) scores using Mn biomarkers of hair or blood. Higher hair concentrations of Mn were consistently associated with lower IQ scores while studies of blood biomarkers and IQ scores had inconsistent findings. Studies of infants and toddlers most frequently measured mental and psychomotor development; findings were inconsistent across biomarkers of $\mathrm{Mn}$ (hair, cord blood, tooth enamel, maternal or child blood and dentin).

Although few studies measured environmental sources of $\mathrm{Mn}$, hair biomarkers were associated with $\mathrm{Mn}$ in drinking water and infant formula. Only one paper quantified the associations between environmental sources of $\mathrm{Mn}$ and blood concentrations.

Conclusion: Hair-Mn was the more consistent and valid biomarker of Mn exposure in school-aged children. Accurate measurement of children's exposure to $\mathrm{Mn}$ is crucial for addressing these knowledge gaps in future studies. However, research on biomarkers feasible for fetuses and infants is urgently needed given their unique vulnerability to excessive Mn.

\footnotetext{
* Correspondence: pmcg@umn.edu

${ }^{2}$ Division of Environmental Health Sciences, School of Public Health,

University of Minnesota, Mayo Building, MMC 807, 420 Delaware St. SE,

Minneapolis, MN 55455, USA

Full list of author information is available at the end of the article
} 
(Continued from previous page)

Keywords: Manganese, Exposure biomarkers, Exposure measurement, Children's neurodevelopment

Abbreviations: ADHD, Attention deficit hyperactivity disorder; As, Arsenic; B-Mn, Blood biomarker of manganese; B-Pb, Blood biomarker of lead; CBC, Children's behavioral checklist; Cd, Cadmium; CHAMCOS, Center for Health Assessment of Mothers and Children of Salinas; Cl, Confidence interval; cm, Centimeter; Cu, Copper; Fe, Iron; FeS, Iron sulfide; g, Gram; GM, Geometric mean; H.A., Health advisory; Hair-Fe, Hair biomarker of iron; Hair-Mn, Hair biomarker of manganese; Hair-Pb, Hair biomarker of lead; HD, Hyperkinetic disorder; Hg, Mercury; I.Q., Intelligence quotient; L, Liter; m3, Cubic meter; MDI, Mental Development Index, Bayley Scales of Infant Development; Mg, Magnesium; mg, Milligram; Mn, Manganese; NS, A statistically nonsignificant association; Pb, Lead; PDI, Psychomotor Development Index, Bayley Scales of Infant Development; PM10, Particulate matter with a diameter of 10 micrometers or less; PM2.5, Particulate matter less than 2.5 microns in width; SD, Standard deviation; SES, Socioeconomic status; WASI, Wechsler Abbreviated Intelligence Test; Water-Mn, Water as an environmental measure of manganese; WISC, Wechsler Intelligence Scale for Children; Zn, Zinc

\section{Background}

Neurodevelopmental disabilities exact a significant toll on children. The global burden of attention deficit hyperactivity disorder (ADHD)/hyperkinetic disorder (HD) was estimated at $5.3 \%$ in 2006 with acknowledgement of the limitations of pooled national estimates [1]. Recent prevalence estimates from the United States (U.S.) identify 4.9 million $(8 \%)$ children are learning disabled and another 5.9 million (9.5\%) have attention deficit disorder [2]. The number of U.S. children diagnosed with learning and behavioral problems has increased with time. From 1998-2000 through 2007-2009, the prevalence of ADHD among children aged 5-17 years grew from $6.9 \%$ to $9.0 \%$ [3]. Smaller, subclinical decrements in brain function are more common than diagnosed disorders and such conditions may decrease children's academic success, disturb behavior, and diminish quality of life [4]. These conditions are associated with a growing list of potential neurotoxicants including manganese $(\mathrm{Mn})$. As with most divalent metals (e.g., iron, lead and cadmium), excessive environmental exposure to Mn adversely affects the brain function in adult humans and pre-clinical (animal) models of maternal-fetal dyads. The health implications for fetuses and infants are a concern given the propensity for Mn accumulation in tissue is higher during development [5], and their rapidly developing brain may be at risk of injury at lower levels of $\mathrm{Mn}$ exposure, relative to older children and adults $[6,7]$. However, the potential adverse effects of excessive levels of $\mathrm{Mn}$ on the infant brain are poorly understood. Manganese is an essential micronutrient that plays a critical role in normal growth and development, particularly for brain development [8]. Humans need Mn in their daily diet because it is required for normal amino acid, lipid, protein, and carbohydrate metabolism [6]. Mn deficiencies are considered rare because $\mathrm{Mn}$ is present in numerous commonly consumed food items such as seafood, nuts, spinach, and tea. However, overexposure to $\mathrm{Mn}$ is also detrimental to health. Accumulation of $\mathrm{Mn}$ in the brain results in neurotoxic effects. Neurons in their early developmental stage are especially sensitive to the neurotoxic effects of $\mathrm{Mn}$ [9]. Animal studies demonstrate that $\mathrm{Mn}$ uptake by the brain is higher in the pre-weaning period, relative to later ages. Exposure to excess Mn in the prenatal and postnatal periods leads to tissue Mn deposition in the striatum and hippocampus [5, 7], brain regions that are important for cognitive function. Increased startle, hyperactivity, and learning and memory deficits are the functional consequences of exposure to excess $\mathrm{Mn}$ during development in rats $[7,10]$. Some of these effects are long-term and persist into adulthood, despite the cessation of exposure to excess $\mathrm{Mn}$ [11]. Mn neurotoxicity is greater with combined prenatal and postnatal exposures than with exposure limited to either prenatal or postnatal period, and is mediated by altered neurotransmission, neuronal apoptosis and mismigration, excitotoxicity and oxidative stress [5]. In addition, Mn may indirectly affect brain function by altering tissue homeostasis of other divalent metals that are important for normal neurodevelopment, such as iron, by altering the expression of transporters that are common to all divalent metals [12].

In adult humans, excess $\mathrm{Mn}$ may result in anxiety, learning and memory deficits, and motor impairment $[13,14]$. Inhalation of $\mathrm{Mn}$ is a long-standing concern for workers in the ferromanganese, iron and steel mining, welding and battery assembly industries that contain extremely high levels of $\mathrm{Mn}$ (>1-5 milligrams $\mathrm{Mn} / \mathrm{meter}^{3}$ or $\mathrm{mg} \mathrm{Mn} / \mathrm{m}^{3}$ ) [6]. Community exposures to $\mathrm{Mn}$ also exist and include air contaminants from industrial activities [15], residential proximity to hazardous waste [16] or ingestion of water with naturally occurring $\mathrm{Mn}[17,18]$. $\mathrm{Mn}$ inhalation may bypass the biliary excretion mechanism and enter the brain through facilitated diffusion and active transport across the blood-brain barrier [19], or be passively transported from the olfactory bulb to the cerebral cortex [20], Mn has been considered to be less toxic when ingested than inhaled because adult humans regulate $\mathrm{Mn}$ absorption in the gastrointestinal tract and usually excrete excess Mn taken orally [21]. However, 
infants' regulatory system is immature thus the risk of tissue $\mathrm{Mn}$ accumulation is greater for fetuses and infants $[6,22]$ raising questions about a World Health Organization's (WHO) [23] decision to suspend guidelines addressing Mn concentrations in water [24].

The former WHO drinking water guideline of 400 micrograms/L for Mn was withdrawn in 2011 as unnecessary with an assertion that this health-based level was well above $\mathrm{Mn}$ concentrations normally found in drinking water [23]. However, Frisbie and colleagues report that over 50 countries have drinking water or potential drinking-water supplies that contain a Mn concentration greater than 400 micrograms /L and argue that protective policy guidance is needed [24]. The US Environmental Protection Agency (EPA) provides Health Advisory (HA) values for unregulated contaminants that may cause non-cancerous health effects. EPA has identified that a lifetime $\mathrm{HA}$ at $0.3 \mathrm{mg} / \mathrm{L} \mathrm{Mn}$ in water is not expected to cause adverse neurological effects [25]. While age-specific exposure limits are not available, for infants younger than 6 months, the lifetime HA of $0.3 \mathrm{mg} / \mathrm{L} \mathrm{Mn}$ in water is recommended for acute exposures of 10 days, given concerns for differences in Mn content in human milk and formula and the possibility of a higher absorption and lower excretion in young infants [25].

A rapidly growing body of literature reveals the complexity of the association between exposure to $\mathrm{Mn}$ and children's adverse neurodevelopmental outcomes given a child's age, developmental and nutritional status (e.g., hemoglobin levels). However, the levels, timing and duration of exposure at which these outcomes may occur, and the potential effect of various routes of exposure to $\mathrm{Mn}$ (e.g., drinking water, dietary practices and contaminated air or soil), are not well established. Furthermore, the mechanisms of Mn toxicity are poorly understood and are complicated by interactions with other toxic metals such as lead $(\mathrm{Pb})[26-28]$ and arsenic (As) $[16,29,30]$ and limited and inconsistent evidence of gender-specific neurological effects (generally greater effects in girls [31, 32], but also found in boys) [33]. Accurate measurement of children's exposure to $\mathrm{Mn}$ is critical to address these knowledge gaps in future studies. Our paper examines the evidence for the association of Mn exposures to children's neurodevelopmental outcomes, focused on the contribution of biomarkers and environmental measures for elucidating the exposure-outcome relationship.

\section{Methods}

We identified studies using PubMed and EMBASE search engines in March of 2016. The searches were conducted by combining the results from a search on 'manganese' combined with the results from a strategy that used the concept of neurological outcomes including the following keywords: 'neurobehavioral manifestations' or 'intelligence' or 'child behavior' or 'child development' or 'psychomotor performance' or 'neuropsychological tests' or 'psychomotor disorders' or 'cognition' or 'intelligence test' or 'intelligence quotient.' The inclusion criteria were that the article was published in English and reported a study that measured both Mn exposure and a neurological outcome in humans aged 0-18 years. Any study that met the selection criteria, regardless of the publication date, was included in an initial phase of review. Measurements of $\mathrm{Mn}$ exposure varied including biomarkers and environmental sources; both types of exposure measurements were included. While various neurological outcomes were assessed, no limits were placed on the types of neurological outcomes examined.

\section{Results}

The searches returned 132 unique references. Fifty-six papers were outside the scope of this review because they were published in languages other than English, were review articles or meeting abstracts, had animal subjects, or did not include both a measure of $\mathrm{Mn}$ exposure and a neurological outcome. Abstracts were reviewed for the remaining 76 articles; ultimately 36 papers met all selection criteria and were included in this paper (Table 1).

Thirty six studies were conducted in thirteen countries investigating populations from the U.S. (six papers), Bangladesh and Mexico (five papers each), Brazil and South Korea (four papers each), Canada (three papers), Italy and China (two papers each), and France, Sweden, Taiwan, the United Kingdom and Uruguay (one paper each). Study designs were primarily cross-sectional $(N=24)$, and less frequently, prospective cohorts $(N=9)$, and case control $(N=3)$, although Collipp et al. [34] augmented the primary cross-sectional study with a secondary case control study (which is not included in the count of study designs). Sample sizes ranged from 16 (cases only) to 1,588 with approximately 7,639 children in total (except for children classified as controls in the case-control studies). Ten studies enrolled newborns. The ages at which neurodevelopmental outcomes were first assessed in relation to $\mathrm{Mn}$ exposure included infants (6 papers), toddlers or preschoolers (3 papers) and school-age children (27 papers). Exposure was more frequently measured with biomarkers (33 papers) than environmental samples (13 papers), (Table 1).

\section{Neurodevelopmental outcomes}

Studies examining the potential for the adverse impact of $\mathrm{Mn}$ on neurological outcomes most frequently assessed measures of IQ [15-18, 26, 30-32, 35-41], infant and toddler development [27, 28, 42-46], motor skills [33, 39, 47-49], attention deficit and hyperactivity disorder [39-41, 50, 51], attention [36, 43, 52, 53] 


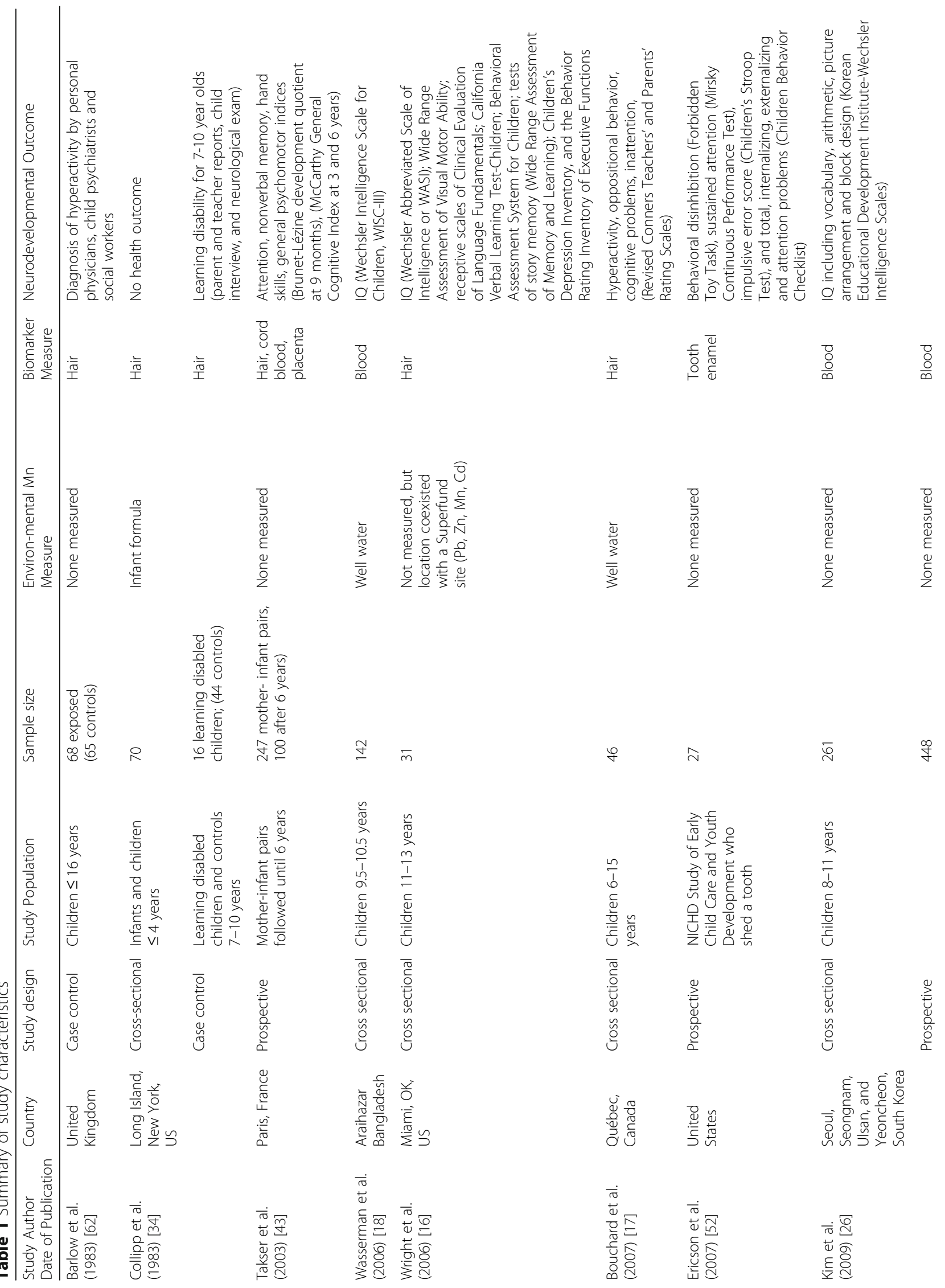




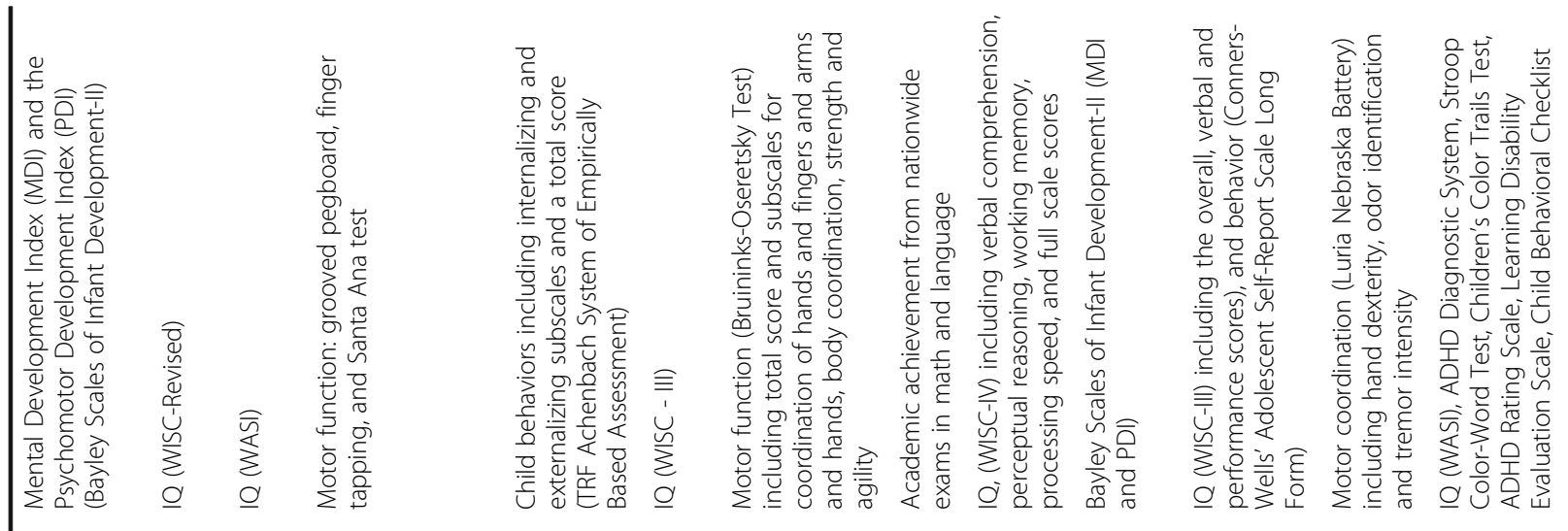

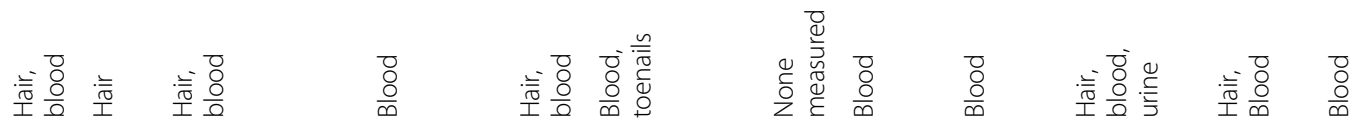
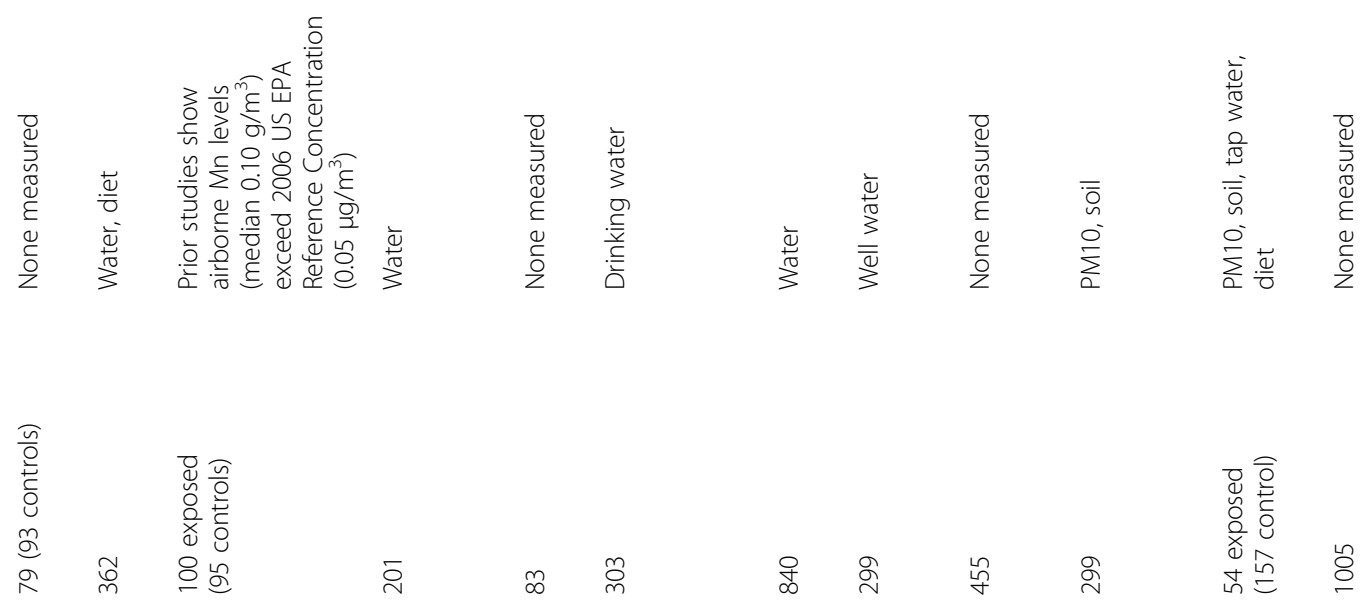

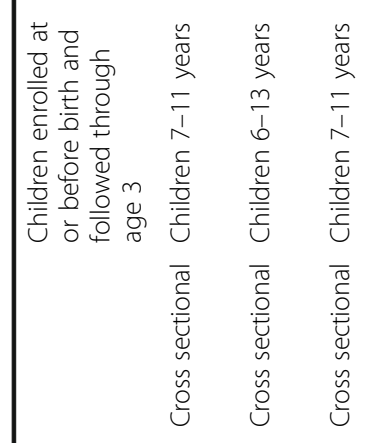

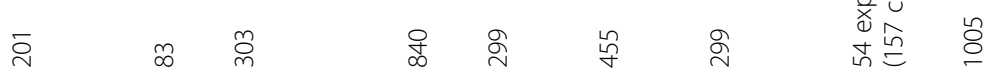

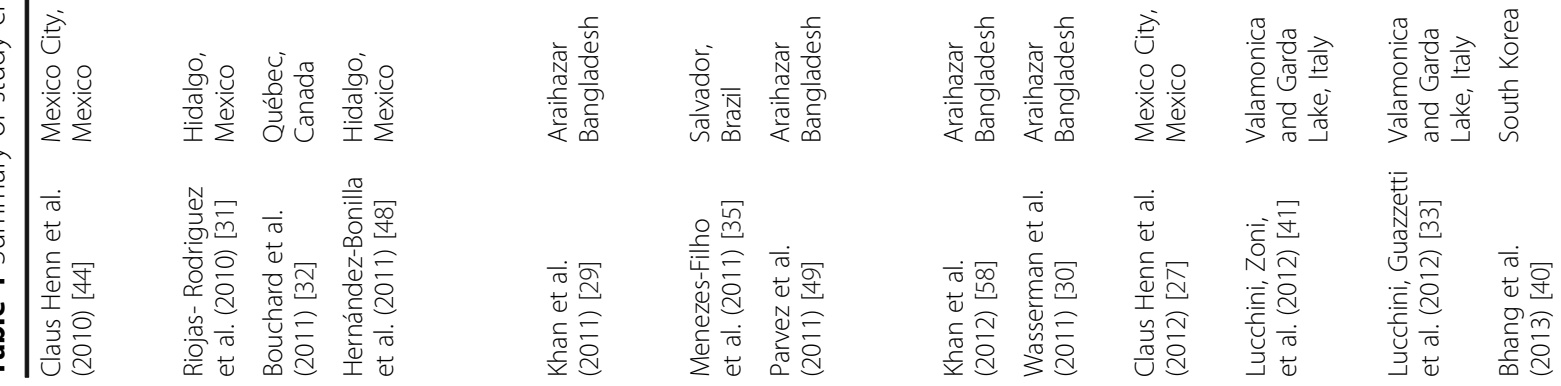




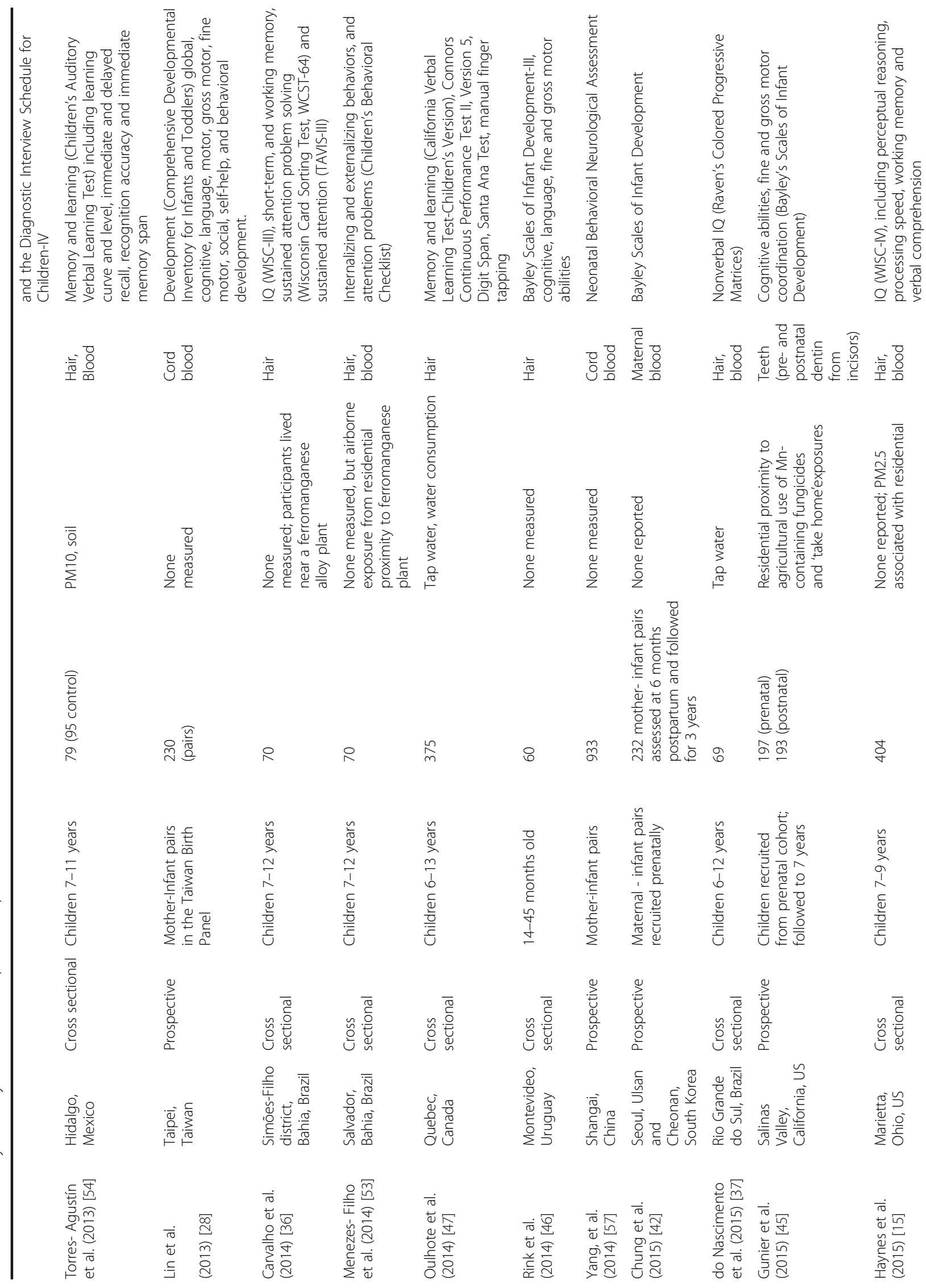




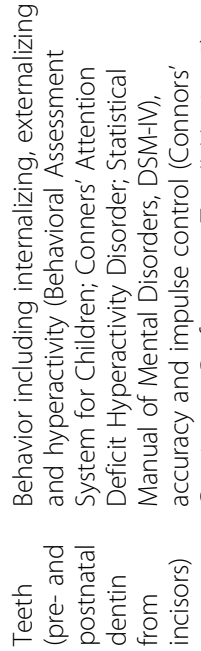

成

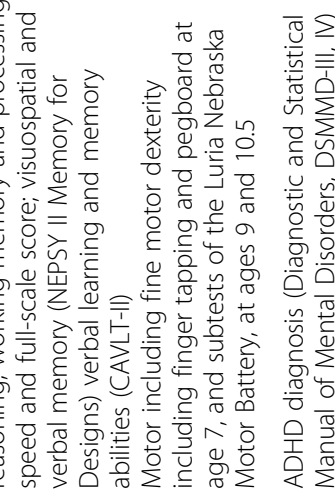

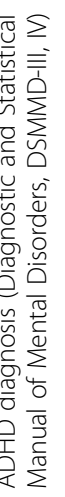

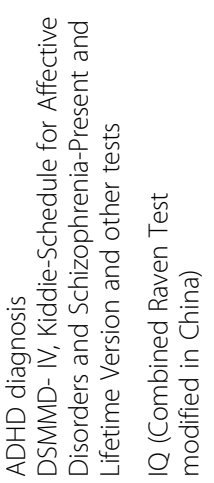

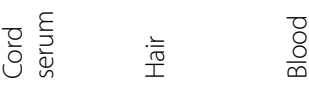

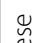

ত

है

है. $\frac{0}{0.0}$

을

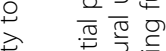

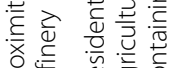

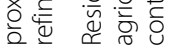

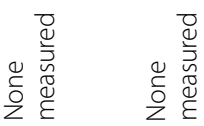

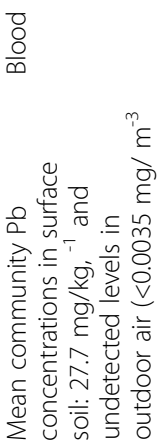

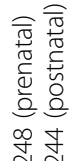

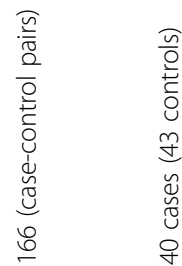

果

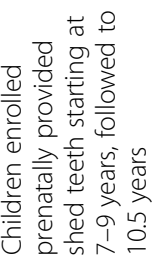

$\stackrel{0}{\infty}$

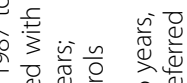

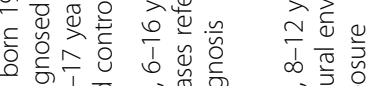

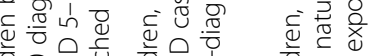

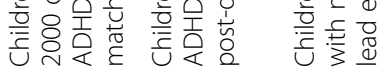

$\stackrel{\infty}{0}$
$\stackrel{0}{0}$
$\stackrel{0}{0}$
$\stackrel{0}{0}$

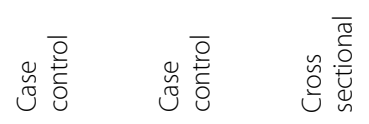

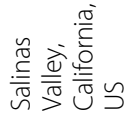

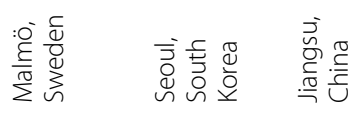

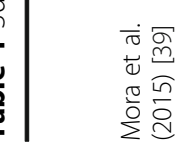

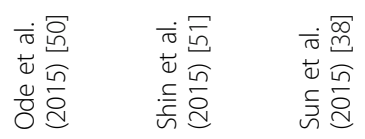


memory $[15,16,30,31,36,39,43,54]$ and behavioral problems [16, 17, 29, 39, 40, 52, 53].

IQ was most frequently studied among children ages $7-14$ years $[15,16,18,26,30-32,35,36,38-41]$ with the Wechsler Intelligence Scale for Children (WISC), consistent with its design for children ages 6 to 16 years and 11 months, using both full-scale IQ (global intelligence) and specific (verbal or performance) scores [55]. Study findings varied across study designs. Lower full-scale IQ scores were associated with increased concentrations of $\mathrm{Mn}$ in six studies investigating IQ as the only neurodevelopmental outcome $[15,26,30,32,35$, 37] and in three additional studies evaluating several neurological outcomes [16, 31, 36]. However, six studies did not report a significant association between IQ and Mn including studies only measuring IQ [18, 31, 35, 38] and one measuring additional outcomes [41]. In contrast to the former studies, Mora et al. examined several neurological outcomes and reported a positive association between postnatal Mn concentrations and IQ only for boys [39].

Motor function was measured in children 7 to 14 years and measures included grooved pegboard (a manipulative dexterity test), finger tapping [33, 39, 46, 47], the Santa Ana test which assesses manual dexterity and motor coordination $[47,48]$, the Bruininks - Oseretsky test which evaluates gross and fine motor functioning [49], the Aiming Pursuit test of hand dexterity [33] and subtests of motor coordination from the Luria Nebraska Battery [33]. Findings varied by study design and measures of outcomes. Mora et al. found higher concentrations of prenatal and postnatal Mn was associated with improved motor outcomes, but only in boys [39]. Oulhote et al. reported a significant association between intake of water-Mn and poorer motor function [47]. Hernández-Bonilla et al. reported a subtle, negative association of Mn with specific areas of motor speed and coordination [48]. Lucchini et al. reported higher $\mathrm{Mn}$ levels associated with poorer motor coordination and hand dexterity, and increased tremor intensity [33]. In contrast to the preceding studies, Parvez et al. did not find associations between $\mathrm{Mn}$ and motor function [49].

Among toddlers and infants ages 1 to 42 months the Bayley Scales of Infant Development (BSID-II) [56] were most frequently used to measure mental and psychomotor development [27, 42, 44, 46, 47]. A significant, inverted U-shaped association between $\mathrm{Mn}$ and development scores was reported in two studies. Chung et al. reported a dose-response relationship with both lower and higher concentrations of $\mathrm{Mn}$ associated with poorer Mental Development Index (MDI) and Psychomotor Development Index (PDI) scores in 6 month old infants [42]. Claus Henn et al. found an association between concurrent MDI scores at 12 (but not 24) months of age, but no association for PDI scores at either time period [44]. Two additional studies reported significant interactions of $\mathrm{Mn}$ and development scores by sex. A significant interaction of postnatal $\mathrm{Mn}$ exposures and poorer 6 month MDI and PDI scores and sex was reported by Gunier et al.; a significant inverse, linear relationship was seen only for girls [45]. A significant, positive interaction between postnatal $\mathrm{Mn}$ and sex was also seen at 24 months, but only for boys who had better MDI scores [45]. Rink et al. also reported a positive association between Mn and MDI scores only in boys, on average 29 months of age [46].

\section{Biomarkers}

Studies generally used biomarkers of children's hair or blood to assess Mn, but a few investigators measured fetal cord blood or serum, maternal blood or children's enamel or dentin from shed teeth; one study measured urine, (Tables 2, 3 and 4). Hair-Mn was the biomarker most consistently associated with a range of neurodevelopmental deficits. Higher levels of hair-Mn in schoolaged children were significantly, and inversely associated with IQ scores [15, 16, 31, 32, 35-37], learning [16, 54], memory [16, 36, 54], perceptual reasoning [15] and positively related with greater hyperactive and oppositional behavior [17, 34].

IQ was the most frequently identified neurodevelopmental deficit associated with hair-Mn. Lower IQ scores were associated with increased concentrations of hair$\mathrm{Mn}$ in four studies investigating IQ as the only neurocognitive outcome [15, 32, 35, 37], but IQ was also determined to be the only significant association with hair$\mathrm{Mn}$ in a fifth study which measured several neurological outcomes [31]. Only one study found no significant association between IQ and $\mathrm{Mn}$ concentrations in hair [41]. In this study the mean Mn concentration in the hair was low, perhaps because Mn exposure in this study was from historical ferroalloy emissions.

Estimates of the effect size of hair-Mn on the average, full scale IQ scores of children, (mean age 9 years), were reported by Bouchard and colleagues to decline slightly (from 106 to 104) with hair-Mn values less than 1.5 micrograms/ $\mathrm{g}$, but significantly so for IQ scores of 101 with mean hairMn values of 3.2 micrograms/g, suggestive of biological significance [32]. Evidence of a U-shaped relationship with both high and low concentrations of hair-Mn associated with lower full scale IQ scores in children, on average, 8 years old were reported by Haynes et al. [15], suggestive of $\mathrm{Mn}$ as both a neurotoxicant and a micronutrient. Study findings revealed a significant, negative association between the highest quartile versus middle two quartiles of hair-Mn ( $ß-3.66$; $95 \%$ CI: -6.9, -0.43) and full scale IQ [15].

Blood-Mn levels were associated with a neurodevelopmental outcome in nine of sixteen papers reviewed. 
Table 2 Summary of results from studies examining manganese concentrations in hair (Hair-Mn or H-Mn)

\begin{tabular}{|c|c|c|c|c|}
\hline Study & $\begin{array}{l}\text { Children's Ages and } \\
\text { Mean Mn Level } \\
(\mu \mathrm{g} / \mathrm{g}),(\mathrm{SD})\end{array}$ & Association with Environmental Mn & $\begin{array}{l}\text { Association with } \\
\text { Neurodevelopment }\end{array}$ & $\begin{array}{l}\text { Other metals' mean } \\
\text { concentrations in hair } \\
(\mu \mathrm{g} / \mathrm{g}),(\mathrm{SD})\end{array}$ \\
\hline $\begin{array}{l}\text { Barlow et al. } \\
\text { (1983) [62] }\end{array}$ & $\begin{array}{l}<16 \text { years } \\
\text { Hyperactive: } 0.84(0.64) \\
\text { Control: } 0.68(0.45)\end{array}$ & None measured & $\begin{array}{l}\text { Hyperactivity was more prevalent } \\
\text { in hyperactive children (mean age: } \\
7.6 \text { years) but at lower levels of } \\
\text { statistical significance ( } 90 \% \\
\text { confidence) using bivariate } \\
\text { analyses. }\end{array}$ & $\begin{array}{l}\text { Lower levels of zinc }(\mathrm{Zn}) \text { were } \\
\text { associated with hyperactive } \\
\text { children: } 83.4 \text { (32.3) compared to } \\
\text { controls: } 99.1 \text { (54.3), } 95 \% \\
\text { confidence using bivariate } \\
\text { analysis. Other metals were } \\
\text { nonsignificant in association with } \\
\text { the outcome including: (Cadmium } \\
(\mathrm{Cd}) \text {, Copper (Cu), Iron (Fe), Lead } \\
(\mathrm{Pb}) \text {, and Magnesium (Mg). }\end{array}$ \\
\hline
\end{tabular}

Collipp et al. Ages $7-10$ years

None measured

(1983) [34] Learning- disabled:0.43

Control: 0.27

Age 4-months Breastfed: 0.33 Formula fed: 0.685

Takser et al. Newborns to 6 years (2003) [43] $\quad 0.75^{1}$

None measured

The measured
Significantly greater hair-Mn in

formula-fed infants.

None measured

Wright et al. 11-13 years

(2006) [16] 0.47

\author{
Bouchard et $\quad 6-15$ years \\ al. (2007) $5.1(4.3)$ \\ [17]
}

$\begin{array}{ll}\text { Hernández- } & 7-11 \text { years } \\ \text { Bonilla et al. } & 12 \text { (exposed) } \\ \text { (2011) [48] } & 0.57 \text { (nonexposed) }\end{array}$
Respiratory Mn exposures were associated with residential proximity to Mn mines, but specific measures were not reported.

Greater $\mathrm{MnH}$ concentrations from children who drank well water with higher Mn-water.
Significantly higher hair-Mn levels from learning disabled children, 710 years old, compared to children without the condition.

None applicable

$$
\text { Not applicable }
$$

Not applicable

No association was found between hair-Mn post-childbirth and general psychomotor developmental indices at 9 months and a general cognitive index at 3 and 6 years in models adjusted for maternal age and education, smoking, labor duration, children's sex and cord blood lead levels and other confounders.

Lower full-scale IQ, verbal learning and memory scores were associated with higher concentrations of hair-Mn from children, on average 12.6 years old, in analyses adjusted for maternal education, child sex and concentrations of lead $\mathrm{PbH}$.

\section{Greater hyperactive and} oppositional classroom behavior was associated with higher hair-Mn from children, on average, 11 years old, in analyses adjusted for age, sex and income. No interaction between hair-Mn and child sex.

Hair-Mn was not associated with neuromotor outcomes (grooved pegboard, finger tapping repetition and Santa Anna test in children, on average, 9 years old in analyses adjusted for $\mathrm{Pb}$ in blood, hemoglobin, sex, age and maternal education.

\section{Menezes- $\quad 6-12$ years}

Filho et al. $\quad 5.83^{1}(11.5)$

(2011) [35] Hair-Mn levels were 6 times higher than those in the general Brazilian population (mean $0.47 \mu \mathrm{g} / \mathrm{g}$, range $0.89-2.15 \mu \mathrm{g} / \mathrm{g}$ )

Riojas7-11 years Rodriguez Exposed: 12.13

et al. (2010) Unexposed: 0.57 [31]
None measured, but $\mathrm{Mn}$ exposures were from residential proximity to Mn alloy production plant.

Median airborne concentration of $\mathrm{Mn}$ in PM10 of exposed $(0.13 \mu \mathrm{g} /$ $\left.\mathrm{m}^{3}\right)$ versus unexposed $\left(0.02 \mu \mathrm{g} / \mathrm{m}^{3}\right)$ communities, but personal exposures were not reported.
Lower full scale and verbal IQ scores in children, on average, 8.8 years old, in analyses adjusted for maternal education and nutritional status. A ten-fold increase of hair-Mn was associated with a 6.7 - point loss in Verbal IQ score.

Lower full scale, verbal and performance IQ scores in children, on average, 9 years old, in analyses adjusted for blood-Pb, hemoglobin, age, sex and nutritional status. Sex
Higher arsenic (As) levels, particularly in combination with higher Mn levels, associated with lower IQ, verbal learning, and memory scores. No associations found with Cd levels.

Not applicable

Not applicable

Children with iron deficiency had higher hair-Mn $(15.94 \pm 19.68 \mu \mathrm{g} /$ g; $p=0.06$ ) compared to those with FeS in normal range $(8.69 \pm$ $8.23 \mathrm{Mn} / \mathrm{g}$ ).

Not applicable 
Table 2 Summary of results from studies examining manganese concentrations in hair (Hair-Mn or H-Mn) (Continued)

\begin{tabular}{|c|c|c|c|c|}
\hline & & & $\begin{array}{l}\text { significantly modified the associ- } \\
\text { ation with the strongest inverse as- } \\
\text { sociation in young girls. There was } \\
\text { little evidence of an association in } \\
\text { boys. }\end{array}$ & \\
\hline $\begin{array}{l}\text { Bouchard et } \\
\text { al. (2011) } \\
\text { [32] }\end{array}$ & $\begin{array}{l}6-13 \text { years } \\
\text { Median: } 0.7\end{array}$ & $\begin{array}{l}\text { Hair-Mn levels were associated } \\
\text { with higher } \mathrm{Mn} \text { in water (Water- } \\
\left.\text { Mn) (mean: } 98 \mu \mathrm{g} / \mathrm{L}, \mathrm{GM}:{ }^{1} 20 \mu \mathrm{g} / \mathrm{L}\right) \text {, } \\
\text { but not in diet. }\end{array}$ & $\begin{array}{l}\text { Lower full-scale IQ scores were as- } \\
\text { sociated with increased hair-Mn } \\
\text { concentrations in children, on aver- } \\
\text { age, } 9 \text { years old, in analyses ad- } \\
\text { justed for maternal intelligence and } \\
\text { education, income, sex and age of } \\
\text { children, Fe concentrations in water } \\
\text { and other confounders. A 10-fold } \\
\text { increase in } \\
\text { water-Mn was associated with a } \\
\text { decrease of } 2.4 \text { IQ points ( } 95 \% \text { Cl:- } \\
3.9 \text { to -0.9, } p<0.01 \text { ) adjusting for } \\
\text { maternal intelligence and other } \\
\text { confounders. Sex stratification } \\
\text { showed a slightly higher impact of } \\
\text { hair-Mn for girls' full-scale IQ, but } \\
\text { the interaction term was nonsignifi- } \\
\text { cant. Water-Mn was more strongly } \\
\text { associated with performance than } \\
\text { verbal IQ. }\end{array}$ & Not applicable \\
\hline $\begin{array}{l}\text { Lucchini, et } \\
\text { al. (2012) } \\
\text { [33] }\end{array}$ & $\begin{array}{l}\text { 11-14 years } \\
0.16 \text { Median }\end{array}$ & $\begin{array}{l}\text { Significant differences for } \mathrm{Mn} \\
\text { concentrations in soil (soil-Mn) and } \\
\text { air (air-Mn) by proximity to } \\
\text { industrial sites with historical Mn } \\
\text { emissions, but not for tap water, } \\
\text { diet or hair. } \\
\text { Impairment of motor coordination, } \\
\text { hand dexterity and odor } \\
\text { identification was associated with } \\
\text { median concentrations of soil-Mn } \\
\text { in exposed ( } 897 \text { ppm) versus refer- } \\
\text { ence ( } 409 \text { ppm) communities. }\end{array}$ & $\begin{array}{l}\text { Tremor intensity in dominant hand } \\
\text { was positively associated with hair- } \\
\text { Mn in children, on average, } \\
12.9 \text { years old, in analyses adjusted } \\
\text { for age, gender, SES, family size, } \\
\text { parity order, parents' education, } \\
\text { smoking habits and soil concentra- } \\
\text { tions of Pb and other metals. Boys } \\
\text { had increased tremor intensity rela- } \\
\text { tive to girls. }\end{array}$ & Not applicable \\
\hline $\begin{array}{l}\text { Lucchini, et } \\
\text { al. (2012) } \\
\text { [41] }\end{array}$ & $\begin{array}{l}11-14 \text { years } \\
0.17\end{array}$ & $\begin{array}{l}\text { No association between } \\
\text { concentrations of hair-Mn with } \\
\text { soil- or air-Mn }\end{array}$ & $\begin{array}{l}\text { No association between hair-Mn } \\
\text { concentrations with full-scale, ver- } \\
\text { bal or performance IQ, or behav- } \\
\text { ioral and attention deficit } \\
\text { hyperactivity scores for children, on } \\
\text { average, } 12.9 \text { years old, with Mn ex- } \\
\text { posure modeled as a main effect } \\
\text { or an interactive term with blood- } \\
\text { Pb in analyses adjusted for age, } \\
\text { gender, family size, SES, area of resi- } \\
\text { dence, hemoglobin, ferritin and } \\
\text { confounders. }\end{array}$ & \\
\hline
\end{tabular}

Torres- $\quad 7-11$ years

Agustín et Exposed: 14.2

al. (2013) Unexposed: 0.73

[54]

Rink et al. $\quad 14-45$ months (2014) [46] $0.98(0.74)$
Greater hair-Mn concentrations in children in exposed group. Mn concentrations in outdoor air from $\mathrm{Mn}$ mining and ranged from the median: $0.08, \mu \mathrm{g} / \mathrm{m}^{3}$ in the exposed location compared to the median: $0.02, \mu \mathrm{g} / \mathrm{m}^{3}$ in the control location.

None measured
Lower long-term memory and learning scores were associated with increased hair-Mn in children, on average, 9 years old, in analyses adjusted for children's sex, blood$\mathrm{Pb}$, age, hemoglobin and maternal education. The negative association was stronger for girls.

Lower scores in cognitive and expressive language tests in children, on average, 28.8 months old, but only in unadjusted models. Boys had a significantly positive association between hair-Mn concentrations and receptive languages scores in analyses adjusted for hair-Pb concentrations, child hemoglobin and age, paternal
Not applicable

Not applicable 
Table 2 Summary of results from studies examining manganese concentrations in hair (Hair-Mn or H-Mn) (Continued)

\begin{tabular}{|c|c|c|c|c|}
\hline & & & $\begin{array}{l}\text { education, maternal IQ, SES, and } \\
\text { other confounders. }\end{array}$ & \\
\hline $\begin{array}{l}\text { Carvalho et } \\
\text { al. (2014) } \\
{[36]}\end{array}$ & $\begin{array}{l}7-12 \text { years } \\
14.6(11.8)\end{array}$ & $\begin{array}{l}\text { None were measured, but } \mathrm{Mn} \\
\text { exposure was related to residential } \\
\text { location and air emissions from an } \\
\text { iron-Mn alloy plant. }\end{array}$ & $\begin{array}{l}\text { Lower full-scale IQ, and lower scores } \\
\text { on Vocabulary, Block Design, and } \\
\text { Digit Span tests were associated } \\
\text { with increased hair-Mn for children, } \\
\text { on average, } 9.4 \text { years old, in analyses } \\
\text { adjusted for maternal education and } \\
\text { children's age. Each } 1 \mu \mathrm{\mu g} / \mathrm{g} \text { increase } \\
\text { in hair-Mn was associated with a de- } \\
\text { crease of approximately } 1 \text { full-scale } \\
\text { IQ point and lower test scores for ex- } \\
\text { ecutive function, strategic visual for- } \\
\text { mation and verbal working memory. } \\
\text { No significant sex differences for } \\
\text { hair-Mn concentrations. }\end{array}$ & \\
\hline $\begin{array}{l}\text { Menezes- } \\
\text { Filho et al. } \\
\text { (2014) [53] }\end{array}$ & $\begin{array}{l}7-12 \text { years } \\
\text { Boys: } 15.3(9.9) \text { Girls: } \\
13.9(13.4)\end{array}$ & $\begin{array}{l}\text { None were measured, but } \mathrm{Mn} \\
\text { exposure was related to residential } \\
\text { location and air emissions from an } \\
\text { iron-Mn alloy plant. }\end{array}$ & $\begin{array}{l}\text { Externalizing behaviors and } \\
\text { attention problems on the Child } \\
\text { Behavior Checklist (CBC) for girls } \\
\text { was significantly associated with } \\
\text { higher hair-Mn. No significant asso- } \\
\text { ciation was found between CBC } \\
\text { scores for boys in sex-stratified } \\
\text { models adjusted for age (with } \\
\text { boys) or maternal IQ (with girls). }\end{array}$ & \\
\hline $\begin{array}{l}\text { Oulhote et } \\
\text { al. (2014) } \\
\text { [47] }\end{array}$ & $\begin{array}{l}\text { 6-13 years } \\
\text { Boys: } 0.75 \\
\text { Girls: } 0.80\end{array}$ & 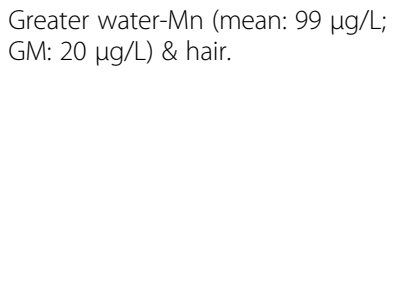 & $\begin{array}{l}\text { Mn exposure was associated with } \\
\text { significant decrements in memory } \\
\text { (hair and water) and attention (hair), } \\
\text { and motor function (water) adjusted } \\
\text { for maternal education and } \\
\text { nonverbal intelligence, tobacco } \\
\text { consumption, child sex, age and } \\
\text { other confounders. Estimates of } \\
\text { associations by sex were similar. }\end{array}$ & \\
\hline $\begin{array}{l}\text { do } \\
\text { Nascimento } \\
\text { et al. (2015) } \\
\text { [37] }\end{array}$ & $\begin{array}{l}6-12 \text { years } \\
\text { Rural: } 2.07(2.6) \\
\text { Urban: } 0.45(0.2)\end{array}$ & $\begin{array}{l}\text { Greater } M n \text { in drinking water } \\
\text { (mean: } 20 \mu \mathrm{g} / \mathrm{L} \text { ) rural sites and } \\
\text { (mean: } 1.0 \mu \mathrm{g} / \mathrm{L} \text { ) urban sites) } \\
\text { associated with greater Mn levels } \\
\text { in hair. }\end{array}$ & $\begin{array}{l}\text { Lower (nonverbal) IQ scores were } \\
\text { associated with hair-Mn and water- } \\
\text { Mn concentrations for children, on } \\
\text { average, } 8.5 \text { years old using models } \\
\text { adjusted for age, gender and par- } \\
\text { ental education. }\end{array}$ & $\begin{array}{l}\text { Additional, similarly specified models } \\
\text { were tested for the association } \\
\text { of } \mathrm{Pb}, \mathrm{Cr}, \mathrm{As}, \mathrm{Hg} \text {, and Fe in hair on } \\
\text { cognitive outcomes. Only hair-Fe } \\
\text { showed a significant and inverse } \\
\text { association with outcomes. }\end{array}$ \\
\hline $\begin{array}{l}\text { Haynes et } \\
\text { al. (2015) } \\
{[15]}\end{array}$ & $\begin{array}{l}7-9 \text { years } \\
0.42^{1}(0.002)\end{array}$ & $\begin{array}{l}\text { Air-Mn associated with home } \\
\text { proximity to ferromanganese } \\
\text { refinery. }\end{array}$ & 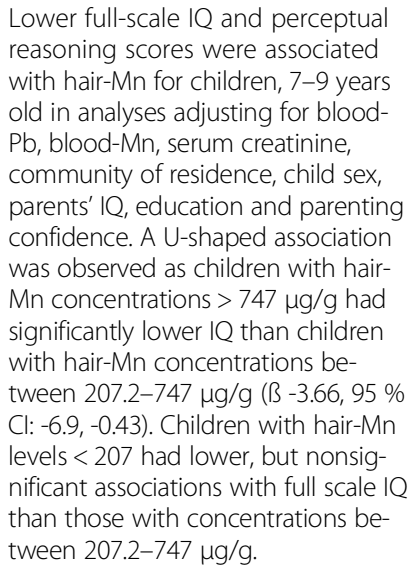 & Not applicable \\
\hline $\begin{array}{l}\text { Shin et al. } \\
\text { (2015) [51] }\end{array}$ & $\begin{array}{l}6-16 \text { years } \\
\text { Case: } 0.31(0.46) \\
\text { Control: } 0.22(0.10)\end{array}$ & None measured & $\begin{array}{l}\text { No association between hair-Mn } \\
\text { and ADHD was found in children } \\
\text { on, average, } 9.7 \text { years old when ana- } \\
\text { lysis was adjusted for confounders of } \\
\text { age, sex and full-scale IQ. }\end{array}$ & Not applicable \\
\hline
\end{tabular}


Most studies reporting associations between blood-Mn and neurological outcomes measured several outcomes. However, seven studies only examined IQ as the primary outcome and the findings were inconsistent. Four investigations did not find an association between IQ and blood-Mn [18, 31, 35, 38], but studies by Haynes et al. [15], Kim et al. [26], Wasserman et al. [30], showed a significant, inverse association between blood-Mn and IQ scores for children, on average, 8-9 years of age with mean concentrations of blood-Mn at 9.7 micrograms/L, 14.3 micrograms/L and 14.8 micrograms/L, respectively. Evidence of an inverse, U-shaped association between low and high levels of blood-Mn and low IQ scores was seen in three studies with children [15, 42, 44], two of which used the same outcome measure. Claus Henn et al. reported a significant association between concurrent MDI scores and blood- Mn in 12 month old infants comparing the middle three $\mathrm{Mn}$ quintiles with the lowest $\mathrm{Mn}$ quintile ( $\beta-3.3,95 \% \mathrm{CI}:-6.0,-0.7)$ and the highest $\mathrm{Mn}$ quintile ( $\beta-2.8,95 \% \mathrm{CI}:-5.5,-0.2)$ [44]. Chung and colleagues also reported a significant, inverse U-shaped association between maternal blood-Mn with infant PDI scores at 6 months. Increasing maternal blood-Mn levels up to $24-28$ micrograms/L were positively associated with PDI scores while higher blood-Mn concentrations were associated with decreased PDI scores suggesting adverse effects of both low ( $<20$ micrograms/L) and (high $\geq 30$ micrograms/L) maternal blood-Mn levels [42].

Evidence for the usefulness of other Mn biomarkers included three papers that reported significant associations between $\mathrm{Mn}$ in cord blood or serum and early life neurodevelopment indicative of the importance of prenatal Mn exposure. Takser et al. reported an inverse association between cord blood-Mn at birth (Geometric Mean: 38.5 micrograms/L) and attention and non-verbal memory in three year olds and a significant, negative association with hand skills, significantly poorer scores in boys [43]. Lin et al. found cord blood-Mn (mean 50.7 micrograms/L; SD: 16.7 micrograms/L) and blood-lead (13.0 micrograms/L; SD: 7.51 micrograms/L) levels above the $75^{\text {th }}$ percentile had a significant association with overall $(\beta-7.03 ; \mathrm{SE}=2.56 ; p=0.009)$, cognitive $(\beta$ -8.19, $\mathrm{SE}=3.17 ; p=0.012)$ and language scores $(\beta-6.81$, $\mathrm{SE}=2.73, p=0.013)[28$ ]. Yang et al. found that a high cord serum-Mn ( $\geq 75^{\text {th }}$ percentile, median: 4.0 micrograms/L) was associated with significantly lower scores on a Neonatal Behavioral Neurological Assessment (NBBA) at 3 days of age [57]. An interactive, protective effect was seen with prenatal selenium (Se); as the $\mathrm{Mn}$ / Se ratio increased, NBNA scores decreased while high levels of Se had a protective effect in the high Mn group $(\mathrm{Mn} \geq 9.1$ micrograms/L; Se $\geq 63.1$ micrograms/L).

Teeth-Mn levels were analyzed in three studies suggestive of their potential value as biomarkers of early life exposures providing insight on the timing of Mn exposure and developmental windows of susceptibility. Ericson et al. measured tooth enamel in shed molars and found significant associations between Mn levels in enamel formed during the first 20 weeks of gestation and increased childhood behavioral inhibition at 36 months [52]. Studies from the Center for the Health Assessment of Mothers and Children of Salinas (CHAMCOS) birth cohort provided findings on the timing of early life $\mathrm{Mn}$ exposures. Gunier et al. reported small decreases in mental and motor development among 6 month old infants in association with prenatal dentin-Mn concentrations, but only for girls whose mothers had lower hemoglobin levels [45]. Additionally, a two-fold increase of postnatal dentin-Mn, reflecting exposures from birth to 2.5 months, was associated with a small, but significant decrease for infants' mental development scores at 6 and 12 months. A significant interaction between postnatal dentin-Mn concentrations and sex for MDI (-1.5 points; $95 \%$ CI: $-2.4,-0.6)$ and PDI $(-1.8$ points; $95 \%$ CI: $-3.3,-0.3)$ scores at 6 months was reported, but only for girls; it was no longer evident by 24 months. Mora et al. reported increased Mn levels in pre-and postnatal dentin adversely associated with behavior problems in school aged children [39]. In contrast, the authors also reported positive effects of pre- and postnatal dentin-Mn specific to boys including better cognition, memory and motor function.

\section{Environmental sources of manganese}

Levels of $\mathrm{Mn}$ in environmental sources were less frequently quantified than biomarkers of Mn. Collipp et al. found higher levels of hair-Mn in infants fed formula relative to breastfed infants [34]. Since the study's publication, levels of $\mathrm{Mn}$ in infant formula have declined. This study was one of the first published papers to show an association between ingestion of dietary $\mathrm{Mn}$ (formula) and hair biomarkers. However, it is unclear if water containing $\mathrm{Mn}$ was used to reconstitute the formula which may have influenced levels of $\mathrm{Mn}$ in hair.

Findings supporting the exposure - outcome relationship between Mn concentrations in water, hair and child neurodevelopment were reported in three papers. Bouchard et al. reported higher levels of hair-Mn in children whose well water had higher Mn levels [32], and higher levels of Mn in water and hair were significantly associated with lower IQ scores. A 10-fold increase of $\mathrm{Mn}$ intake from water consumption was associated with a decrease of 2.5 IQ points (95\% CI:-3.9, $-0.9 ; p<0.01$ ) among 9 year olds [32]. Oulhote et al. reported higher concentrations of $\mathrm{Mn}$ in hair and water were associated with poorer scores on memory, attention and motor function from the same population [47]. Average Mn water levels in this study were lower than the earlier 
Table 3 Summary of results from studies examining manganese concentrations in blood (blood-Mn)

\begin{tabular}{|c|c|c|c|c|}
\hline Study & $\begin{array}{l}\text { Mean Mn } \\
\text { Level }(\mu \mathrm{g} / \\
\mathrm{L}),(\mathrm{SD})\end{array}$ & Association with Environmental Mn & $\begin{array}{l}\text { Association with } \\
\text { Neurodevelopment }\end{array}$ & $\begin{array}{l}\text { Association of other metals' mean } \\
\text { (SD) concentrations in blood, with } \\
\text { the outcome }\end{array}$ \\
\hline $\begin{array}{l}\text { Wasserman } \\
\text { et al. (2006) } \\
\text { [18] }\end{array}$ & $\begin{array}{l}10 \text { year olds } \\
12.8(3.2)\end{array}$ & $\begin{array}{l}\text { No association was found with water-Mn } \\
\text { (Mean: } 795 \mu \mathrm{g} / \mathrm{L} \text { ). }\end{array}$ & $\begin{array}{l}\text { No association was found between } \\
\text { blood-Mn concentrations and overall, } \\
\text { verbal and performance IQ scores in } \\
\text { adjusted analyses, but water-Mn was } \\
\text { associated with lower full-scale, per- } \\
\text { formance and verbal IQ raw scores in } \\
\text { a dose-dependent fashion. }\end{array}$ & $\begin{array}{l}\text { Blood-Mn was not significantly } \\
\text { correlated with blood-Pb or blood- } \\
\text { As. When all three blood metals were } \\
\text { included in analyses only mean } \\
\text { blood-Pb concentrations, } 12 \mu \mathrm{g} / \mathrm{dL} \\
\text { (3.7) were associated with IQ scores. }\end{array}$ \\
\hline
\end{tabular}

$\begin{array}{ll}\text { Kim et al. } & 8-11 \text { years }\end{array}$ None measured

Claus Henn 12 month: et al. (2010) $24.3(4.5)$

[44] 24 month: $21.1(6.2)$

None measured

$\begin{array}{ll}\text { Riojas- } & 7-11 \text { year } \\ \text { Rodriguez } & \text { olds } \\ \text { et al.(2010) } & 9.7^{\mathrm{a}} \\ \text { [31] } & \text { (Exposed) } \\ & .2 \text { (Control) }\end{array}$

Hernández- 7-11 year

Bonilla et al. olds

8.0 (Control)
(2011) [48] 9.5 (Exposed)

24-h median $\mathrm{Mn}$ in PM10 for the exposed $\left(0.13 \mu \mathrm{g} / \mathrm{m}^{3}\right)$ and control $\left(0.02 \mu \mathrm{g} / \mathrm{m}^{3}\right)$ communities

Prior studies show airborne Mn levels (median $0.10 \mu \mathrm{g} / \mathrm{m}^{3}$ ) exceed EPA 1999 Reference Concentrations $\left(0.05 \mu \mathrm{g} / \mathrm{m}^{3}\right)$.

Kahn et al. 8-11 year (2011) [29] olds $15.1(3.9)$
Non-significant association of blood-Mn with water-Mn (mean: $900 \mu \mathrm{g} / \mathrm{L}$ ).
None measured; Mn exposure was due to home proximity to $\mathrm{Mn}$ alloy production.
Blood-Mn had an inverse, U-shaped association with a concurrent measure of the Mental Development Index (MDI) scores at 12 months of age. Declines of 3.4 and $2.8 \mathrm{MDI}$ points for the lowest and highest quintiles of blood-Mn relative to the middle three quintiles, correspond to declines of 0.37 and 0.31 SD units in the MDI. This association declined by 24 months and was nonsignificant in adjusted analyses including blood$\mathrm{Pb}$, sex, maternal IQ and education, hemoglobin and gestational age. No association was found with the PDI score.

Exposed children showed nonsignificant, inverse associations of blood-Mn with lower full scale, verbal and performance IQ scores compared to controls. Analyses were adjusted for age, sex, hemoglobin, maternal education, blood-Pb. Differences by sex were nonsignificant.

Blood-Mn was inversely associated with poorer finger tapping in analyses adjusted for age, sex, maternal education, hemoglobin and blood- $\mathrm{Pb}$. Other motor function measures (grooved pegboard and Santa Anna test scores) were not significantly associated with blood-Mn. Sex differences for blood-Mn were nonsignificant.

No association was found between blood-Mn and externalizing (attention problems and aggression) and internalizing (anxiety) behaviors and a total behavioral score in analyses adjusted for water-As, water-Mn, urinary creatin-adjusted As and blood-As, sex, maternal education and other variables.

Blood-Mn concentrations were not associated with IQ scores in analyses
Blood- $\mathrm{Pb}$ concentrations of $1.73 \mu \mathrm{g} /$ $\mathrm{dL}(0.8)$ were associated with IQ scores in adjusted analyses with evidence of an additive interaction with blood-Mn. Effect modification was suggested as IQ scores of children with blood-Mn $>14 \mu \mathrm{g} / \mathrm{L}$ were significantly associated with blood$\mathrm{Pb}$ whereas scores for children with blood-Mn $<14 \mu \mathrm{g} / \mathrm{L}$ were not.

Blood-Pb (cord, 12 and 24 month) concentrations were positively associated with 24 month blood-Mn concentrations. Indices of iron status (hemoglobin, ferritin) were inversely associated with $\mathrm{Mn}$ at 12 and 24 months of age.

Blood-Pb was higher in control $(7.96 \mu \mathrm{g} / \mathrm{dL})$ versus $\mathrm{Mn}$-exposed (3.37 $\mu \mathrm{g} / \mathrm{dL})$ children and was correlated with blood-Mn $(r-0.24)$ in the population. It was not significantly associated with IQ outcomes.

Blood-Pb concentrations were higher in the Mn control (median: $8 \mu \mathrm{g} / \mathrm{dL}$ ) versus the Mn exposed (median:

$3.3 \mu \mathrm{g} / \mathrm{dL}$ ) children. The associations with the outcomes were not reported.

There was no statistical association between biomarkers of As (blood or urine) with blood-Mn

Blood-Pb was above $2 \mu \mathrm{g} / \mathrm{dL}$ for $51 \%(n=36)$ and there was no 
Table 3 Summary of results from studies examining manganese concentrations in blood (blood-Mn) (Continued)

\begin{tabular}{|c|c|c|c|}
\hline & & & $\begin{array}{l}\text { adjusted for blood-Pb or low serum } \\
\text { iron levels. }\end{array}$ \\
\hline $\begin{array}{l}\text { Parvez et al. } \\
(2011)[49]\end{array}$ & $\begin{array}{l}\text { 8-11 year } \\
\text { olds } \\
17.7 \text { (3.7) }\end{array}$ & $\begin{array}{l}\text { Water-Mn (mean: } 725.5 \mu \mathrm{g} / \mathrm{L}) \text {. Children } \\
\text { with higher water } \mathrm{Mn}(>500 \mu \mathrm{g} / \mathrm{L}) \text { did } \\
\text { not have higher levels of blood-Mn }(14.5 \\
\text { vs. } 15.0 \mu \mathrm{g} / \mathrm{L} ; p<0.05) .\end{array}$ & $\begin{array}{l}\text { No significant associations were } \\
\text { found between blood-Mn and motor } \\
\text { function measures (fine manual con- } \\
\text { trol, manual and body coordination, } \\
\text { strength and agility). }\end{array}$ \\
\hline
\end{tabular}

Wasserman 8-11 year

et al. (2011) olds

[30] $14.78(3.7)$
Water-Mn (mean: 725.54) and blood-Mn did not vary predictably across groups with high and low levels of water-Mn.
Higher blood-Mn was associated

$\begin{array}{ll}\text { Claus Henn } & 12 \text { months: } \\ \text { et al. (2012) } & 24.7(5.9) \\ \text { [27] } & 24 \text { months: } \\ & 21.5(7.4)\end{array}$

Lucchini et 11-14 year

$\begin{array}{ll}\text { al. (2012) } & \text { olds } \\ \text { [33] } & 11.11 \mu \mathrm{g} / \mathrm{dL}\end{array}$

Lucchini et al. (2012) [41]
11-14 year olds $11.11 \mu \mathrm{g} / \mathrm{dL}$
Mn was measured in air PM10 airborne particles (median: $31.4 \mathrm{ng} / \mathrm{m}^{3}$ vs.

$24.7 \mathrm{ng} / \mathrm{m}^{3}$ ) and soil (median:897 ppm vs. $409 \mathrm{ng} / \mathrm{m}^{3}$ ) in impacted compared to control areas, and water (below LD at $1 \mu \mathrm{g} / \mathrm{L}$ ) and diet (median $2.66 \mathrm{mg} /$ day) with no differences by locations. Soil-Mn was significantly, inversely associated with performance on the olfactory test.

Mn was measured in soil (median: 529.12 ppm), air: (median: $29.37 \mu \mathrm{g} / \mathrm{m}^{3}$ ), water, and diet
TorresAgustín et al. (2013) [54]
7-11 year

olds

Exposed: $9.5^{\mathrm{b}}$ Unexposed: 8.0
Bhang et al. 8-11 year (2013) [40] olds $14.42(4.1)$
Air sampling (PM10) conducted and Mn concentrations in outdoor air from $\mathrm{Mn}$ mining significantly higher for exposed (Outdoor median: $0.08 \mathrm{mg} / \mathrm{m}^{3)}$ versus comparison group (Outdoor median: $0.08 \mathrm{mg} / \mathrm{m}^{3}$ ) Significantly greater blood$\mathrm{Mn}$ concentrations in exposed than comparison children.

None measured with lower perceptual reasoning and working memory scores in analyses adjusted for maternal intelligence and age, children's time in school, plasma ferritin, blood-As and other variables. Significant associations were not found for full scale $I Q$, verbal comprehension or processing speed scores.

A synergistic interaction between lead and $\mathrm{Mn}$ for mental and psychomotor development scores was found at 12 (but not 24) months; greater lead toxicity with higher $\mathrm{Mn}$ levels in analyses adjusted for sex, hemoglobin, gestational age, maternal education and $\mathrm{IQ}$. There were no significant sex differences in blood-Mn.

Tremor intensity, dominant hand, was significantly and positively associated with blood-Mn in adjusted models (including parental smoking and alcohol use, and $\mathrm{Mn}$ in soil, air and hair). Sex differences were found with boys having lower increased tremor intensity.

Mn was not associated with IQ (full scale, verbal and performance) or behavioral (hyperactivity, attention deficit) scores in adjusted analyses.

No significant associations between blood-Mn and verbal learning or memory in adjusted analyses. association with blood-Mn or serumFe (mean: $55.6 \mu \mathrm{g} / \mathrm{dL}$ ).

Blood-Mn correlated slightly with blood-As (mean: $4.8 \mu \mathrm{g} / \mathrm{L}$; SD: 3.2; $r=$ $0.12 ; p=0.02$ ) and moderately with blood-Se (mean: $104.9 \mu \mathrm{g} / \mathrm{L}$; SD:17.2; $r=-0.33, p<0.0001)$. There was a significant, inverse association between As exposure measures (blood, water, urinary and nails) and overall motor function, and a significant association between blood-Se and manual coordination in adjusted analyses. No significant association was found between blood-Pb and motor function.

Increased concentrations of blood-As (mean: $4.81 \mu \mathrm{g} / \mathrm{L} ; \mathrm{SD}$ : 3.22) were significantly associated with lower verbal comprehension in adjusted analyses. However, Mn by As interactions were not significant in adjusted models predicting $\mathrm{IQ}$.

Concentrations of blood-Pb at 12 (mean:5.1 $\mu \mathrm{g} / \mathrm{dL}$; SD: 2.6) and 24 months (mean: $4.8 \mu \mathrm{g} / \mathrm{dL}$; SD: 2.5).

Blood-Pb concentrations in the $\mathrm{Mn}$ exposed (mean: $1.72 \mu \mathrm{g} / \mathrm{dL}$ ) and control (mean: $1.6 \mu \mathrm{g} / \mathrm{dL}$ ) communities were very low.

Blood-Pb concentrations averaged $1.71 \mu \mathrm{g} / \mathrm{dL}$ and were adversely associated with cognitive measures in adjusted analyses declining about 2.4 IQ points with a two-fold increase of blood-Pb. A bench-mark level of blood-Pb was associated with loss of $1 \mathrm{IQ}$ point at $0.19 \mu \mathrm{g} / \mathrm{dL}$ and a lower $95 \% \mathrm{Cl}$ of $0.11 \mu \mathrm{g} / \mathrm{dL}$. No interaction of $\mathrm{Pb}$ and $\mathrm{Mn}$ was observed.

Blood-Pb concentrations were significantly higher in the comparison group $(8.0 \mu \mathrm{g} / \mathrm{dL})$ than the $\mathrm{Mn}$ exposed group $(3.3 \mu \mathrm{g} / \mathrm{dL})$ and included in multivariate models of $\mathrm{Mn}$ exposure.

Excess blood-Mn was associated with Analyses were adjusted for blood-Pb lower scores in thinking, reading, cal- and cotinine. culation, and learning scores and higher cognitive inhibition test scores 
Table 3 Summary of results from studies examining manganese concentrations in blood (blood-Mn) (Continued)

\begin{tabular}{|c|c|c|c|c|}
\hline & & & $\begin{array}{l}\text { in analyses adjusted for maternal and } \\
\text { child age and IQ, child sex, and age, } \\
\text { cotinine, blood-Pb and other vari- } \\
\text { ables. Lower blood-Mn was associ- } \\
\text { ated with lower cognitive inhibition } \\
\text { scores. }\end{array}$ & \\
\hline $\begin{array}{l}\text { Chung et al. } \\
\text { (2015) [42] }\end{array}$ & $\begin{array}{l}\text { Maternal, } \\
\text { pre- delivery, } \\
30.1 \pm \\
3.5 \text { years; } \\
22.5(6.5)\end{array}$ & Not measured & $\begin{array}{l}\text { Inverted U-shaped dose- response } \\
\text { curve with lower psychomotor devel- } \\
\text { opment scores in infants at } 6 \text { months } \\
\text { with both low and high levels of Mn. } \\
\text { Adjusted mean PDI (but not MDI) } \\
\text { scores differed significantly across } \\
\text { Mn concentration groups. No differ- } \\
\text { ences in effects by sex were } \\
\text { observed. }\end{array}$ & None reported. \\
\hline $\begin{array}{l}\text { do } \\
\text { Nascimento } \\
\text { et al. (2015) } \\
{[37]}\end{array}$ & $\begin{array}{l}6-12 \text { year } \\
\text { olds } \\
\text { Rural: } 16.0 \\
\text { (4.2) } \\
\text { Urban: } 19.0 \\
\text { (4.3) }\end{array}$ & $\begin{array}{l}\text { Water-Mn concentrations differed } \\
\text { significantly between rural (mean: } \\
0.20 \mu \mathrm{g} / \mathrm{L} \text { ) and urban (mean:1.0 } \mu \mathrm{g} / \mathrm{L} \text { ) } \\
\text { children; associations with blood-Mn } \\
\text { were not reported. }\end{array}$ & $\begin{array}{l}\text { No significant associations found for } \\
\text { blood-Mn and nonverbal IQ in ana- } \\
\text { lyses adjusting for age, parents edu- } \\
\text { cation and child sex. }\end{array}$ & $\begin{array}{l}\text { No associations were found between } \\
\text { metals in blood and serum ( } \mathrm{Pb}, \mathrm{Cr} \text {, } \\
\mathrm{As}, \mathrm{Hg} \text { and } \mathrm{Fe} \text { ) and nonverbal IQ. }\end{array}$ \\
\hline $\begin{array}{l}\text { Haynes et } \\
\text { al. (2015) } \\
{[15]}\end{array}$ & $\begin{array}{l}7-9 \text { year olds } \\
9.67(1.27)^{c} \\
{[2]}\end{array}$ & $\begin{array}{l}\text { Mn exposure resulted from residential } \\
\text { proximity to ferromanganese refinery } \\
\text { although measurements relative to the } \\
\text { blood-Mn and the cognitive outcomes } \\
\text { were not reported. }\end{array}$ & $\begin{array}{l}\text { Blood-Mn was significantly associated } \\
\text { with lower full scale IQ, perceptual } \\
\text { reasoning, lower processing speed } \\
\text { scores in analyses adjusted for hair- } \\
\text { Mn, serum cotinine, blood-Pb, and } \\
\text { community residence. Full scale IQ } \\
\text { scores among children in the highest } \\
\text { quartile of blood-Mn ( }>11.2 \mu \mathrm{g} / \mathrm{L} \text { ) } \\
\text { were significantly lower than scores } \\
\text { in children with blood-Mn between } \\
8.2 \mu \mathrm{g} / \mathrm{L} \text { to } 11.2 \mu \mathrm{\mu g} / \mathrm{L}(-3.51 \text { points; } \\
95 \% \mathrm{Cl}:-6.64,-0.38) \text {. Children with } \\
\text { the lowest quartile of blood-Mn } \\
(<8.2 \mu \mathrm{g} / \mathrm{L}) \text { also had lower full scale } \\
\text { IQ scores than children in the refer- } \\
\text { ence group although findings were } \\
\text { nonsignificant (-2.14 points; } 95 \% \mathrm{Cl} \text { : } \\
-5.37,1.09) \text {. The perceptual reasoning } \\
\text { and processing speed scores had the } \\
\text { strongest negative associations with } \\
\text { blood-Mn. }\end{array}$ & $\begin{array}{l}\text { Correlations between biomarkers } \\
\text { found statistically significant } \\
\text { included: blood-Mn and serum ferra- } \\
\text { tin (mean: } 34.4 \mathrm{ng} / \mathrm{mL} ; \mathrm{r}-0.19, p< \\
0.01) \text {, blood-Mn and blood-Pb (mean: } \\
0.82 \mu \mathrm{g} / \mathrm{dL} ; \mathrm{r}-0.13, p=0.02) \text {, and } \\
\text { serum cotinine }(0.08 \mu \mathrm{g} / \mathrm{L} \text { ) and } \\
\text { blood-Pb }(r=0.34, p<0.0001) \text {. Blood- } \\
\mathrm{Pb} \text { was significantly associated with } \\
\text { processing speed, but not full scale } \\
\mathrm{IQ} \text { or other subscales. Cotinine was } \\
\text { significantly associated with full scale } \\
\text { IQ, perceptual reasoning, working } \\
\text { memory and verbal comprehension. }\end{array}$ \\
\hline $\begin{array}{l}\text { Sun et al. } \\
\text { (2015) [38] }\end{array}$ & $\begin{array}{l}8-12 \text { year } \\
\text { olds } \\
16.2 \mu \mathrm{g} / \mathrm{L}\end{array}$ & Not measured & $\begin{array}{l}\text { Blood-Mn was not significantly } \\
\text { associated with IQ, but it was } \\
\text { associated with urinary retinol } \\
\text { binding protein (RBP) which was } \\
\text { associated with blood-Mn. }\end{array}$ & $\begin{array}{l}\text { Blood-Pb (GM: } 33.7 \mu \mathrm{g} / \mathrm{L}) \text { was } \\
\text { significantly, inversely associated with } \\
\text { IQ. }\end{array}$ \\
\hline
\end{tabular}

\footnotetext{
a Geometric Means are given for exposed and control groups

b Median values for BMn

${ }^{c}$ Geometric Mean (GM) and Standard Deviation (GSD)
}

study (20 micrograms/L. vs 300 micrograms/L.). do Nascimento et al. also reported higher levels of $\mathrm{Mn}$ in hair and household tap water were associated with poorer IQ scores in children 6-12 years [37].

Only one study reported blood levels of Mn associated with both a measured environmental source and neurodevelopmental outcomes. Lucchini et al. reported levels of $\mathrm{Mn}$ in blood and hair were both positively associated with tremor intensity in the dominant hand; the authors also found a borderline association between soil-Mn and tremor intensity [33]. Comparisons between the exposed and reference communities revealed average concentrations of $\mathrm{Mn}$ in soil (958 ppm versus $427 \mathrm{ppm}$ ), respectively. The authors describe metals in soil as good indicators of general environmental insult given their stability over time in the environment reflecting both background soil deposition and cumulative inputs from atmospheric deposition of historical industrial emissions.

Two additional studies reported higher levels of $\mathrm{Mn}$ in both the hair and the blood of children who lived near an industrial source of $\mathrm{Mn}[15,31]$. Haynes et al. reported low and high Mn levels in blood and hair were associated with lower full IQ and subscale scores, with significant negative associations between the highest 
Table 4 Summary of results from studies examining manganese in teeth

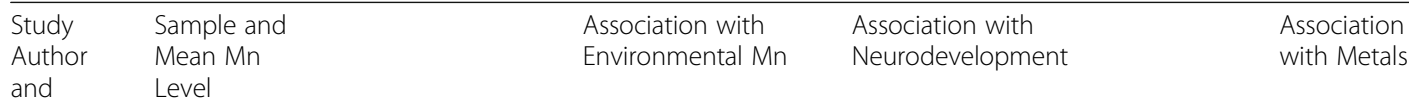

Publication ( $\mu \mathrm{g} / \mathrm{L}),(\mathrm{SD})$

Date

Ericson et Children from a maternal prenatal None measured

al. (2007) cohort that provided shed molars at

[52] 11-13 years. Mn concentrations

from teeth enamel were measured but values not reported.

Children from a maternal prenatal cohort provided shed teeth starting at age 7. Mn from dentin of deciduous teeth [2] Prenatal: 0.51 (0.19) Postnatal: $0.20(0.23)$
Not reported, but related to residential proximity or use of agricultural fungicides with $\mathrm{Mn}$.
None reported, but exposure related to agricultural exposures to Mn-containing fungicides.
Mora et al. Children from two integrated (2015) [39] prenatal cohort samples provided teeth at 7-9 years.

Mn from dentin of deciduous teeth: Prenatal: 0.46 (1.48); Postnatal: 0.14 (2.47)

\begin{abstract}
Prenatal Mn levels, representing exposures from the $20^{\text {th }}$ gestational week were positively associated with behavioral outcomes: higher levels of disinhibition (36 months), impulsivity (4.5 years), externalizing and internalizing problems $\left(1^{\text {st }}\right.$ and $3^{\text {rd }}$ grades) and disruptive behaviors ( $3^{\text {rd }}$ grade). No differences on standardized tests of cognitive ability or achievement. Analyses were adjusted for mothers' education, family income and child ethnicity. Postnatal Mn levels, representing exposures from gestational weeks 62-64, only correlated with teachers' reports of externalizing behaviors $\left(1^{\text {st }}\right.$ and $3^{\text {rd }}$ grades).
\end{abstract}

Prenatal Mn levels were not associated with MDI or PDI at 6, 12 or 24 months and no interactions by sex.

A two-fold increase in postnatal dentin- Mn levels was associated with small, significant decreases in $\mathrm{MDI}$ at 6 and 12 months (but NS at 24 months). Postnatal dentin-Mn levels were inversely related (but NS) with PDI scores at 6 months, but not 12 or 24 months.

Effect modification by sex was reported with significant interactions between prenatal $\mathrm{Mn}$ and maternal hemoglobin (HGB) in girls at 6 months.

Behavior: No significant associations for prenatal $\mathrm{Mn}$ and behavioral outcomes in children ages 7, 9 or 10.5 years. Higher postnatal Mn was significantly associated with maternal reports of hyperactive, internalizing and externalizing behaviors for children aged 7 years, but not at older ages.

Cognition: Neither prenatal nor postnatal Mn was consistently and significantly associated with cognitive outcomes. A sex effect was shown only for boys with a positive, significant relationship between postnatal $\mathrm{Mn}$ and cognitive scores (full scale, verbal comprehension, and perceptual reasoning $(\mathrm{Q})$ at ages 7 and 10.5 years, and working memory IQ at 7 years.

Memory: Higher prenatal dentin Mn levels associated with significantly better memory scores for children ages 9 and 10.5 and in sex stratified analyses. Postnatal Mn levels were not associated with memory scores
No association between pre- and postnatal Mn ( $r=0.13$, NS [1]), Mn and $\mathrm{Pb}$ (prenatal $r=0.09$, NS; postnatal $r=-.08$, NS).

A significant association was seen with prenatal $\mathrm{Mn}$ and $\mathrm{Fe}(r=0.74, p$ $<0.001)$ but not postnatal $\mathrm{Mn}(\mathrm{r}=-$ $.06, \mathrm{NS})$.

Girls whose mothers had lower prenatal hemoglobin (HGB,

$<11.6 \mathrm{~g} / \mathrm{dL}$ ) had a decrease of 10.5 points (95\%Cl: $-16.2,-4.8 ; n=38$ ) on the $\mathrm{MDI}$ and 11.6 points $(95 \% \mathrm{Cl}$ : $19.3,-3.9)$ on the PDI per two-fold increase in prenatal $\mathrm{Mn}$ at 6 months.

No interactions with blood-Mn and blood-Pb observed or any relationships with neurodevelopment at 24 months.

Higher prenatal Mn levels were associated (NS) with poorer visual spatial memory outcomes at

9 years and poorer cognitive scores at 7 and 10.5 years in children with higher $\mathrm{Pb}$ levels $(\geq 0.8 \mu \mathrm{g} / \mathrm{dL})$. 
Table 4 Summary of results from studies examining manganese in teeth (Continued)

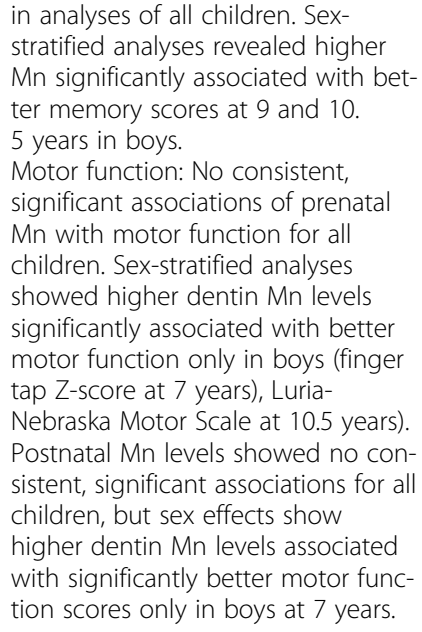

${ }^{a}$ NS refers to a statistical association that is not significant

${ }^{\mathrm{b}}$ Geometric Means and Standard Deviations

versus middle two quartiles of blood-Mn ( $\beta-3.51 ; 95 \%$ CI: $-6.64,-0.38)$ and hair-Mn ( $(-3.66 ; 95 \%$ CI: -6.9 , -0.43 ) and full scale IQ in children ages 7-8 years [15]. Riojas-Rodriguez et al. found hair-Mn was inversely associated with verbal IQ ( $ß-0.29$; 95\%CI: $-0.51,-0.08)$, performance IQ ( $\beta-0.08$; $95 \% \mathrm{CI}$ : $-0.32,-0.16)$, and total IQ ( $\beta-0.20 ; 95 \% \mathrm{CI}:-0.42,0.02)$, in children ages $7-11$ years [31]. The authors reported the $24 \mathrm{~h}$ median $\mathrm{Mn}$ in PM10 in exposed communities (0.13 micrograms $/ \mathrm{m}^{3}$ ) was higher than the exposed communities (0.02 micrograms $/ \mathrm{m}^{3}$ ).

Finally, Kahn et al. reported an inverse association between $\mathrm{Mn}$ in drinking water and children's annual test scores in mathematics [58]. Levels of $\mathrm{Mn}$ in water above 400 micrograms/L (the former WHO standard) was associated with a 6.4 percentage score loss $(95 \% \mathrm{CI}=0.5$, 12.3) in test scores. This study did not test any Mn biomarkers, but a prior paper showed a lack of association between blood-Mn and water-Mn [29].

\section{Discussion}

A growing body of literature has examined the association of increased levels of $\mathrm{Mn}$ with neurodevelopmental effects in children from across the world. The evidence is most consistent in studies reporting decrements in IQ scores among primary school-aged children exposed to excessive levels of Mn. However, the inconsistency of findings in other studies reflects, in part, the considerable variation in study design including the source of Mn (water, air, or soil), exposure pathway (ingestion or inhalation), biomarkers measured (blood, hair, teeth, urine), study population (age, sex, and developmental and nutritional status) and neurological outcomes examined (IQ, motor skills, infant or early childhood development).
A recent pilot study tested the use of fMRI to reveal specific brain changes associated with Mn exposure. The findings revealed long-term exposure to $\mathrm{Mn}$ in the first stage of life can decrease olfactory function. There was also evidence that $\mathrm{Mn}$ exposure can adversely affect the functionality of the limbic system which the authors describe as suggestive of an alteration of the brain network in addressing emotional responses [59]. While scientifically promising, this approach may be less feasible for large, population studies of infants and young children given the expense and potential resistance of parents to having their children scanned for research in the absence of disease. However, with further testing in larger samples this approach could complement the use of biomarkers in studies of Mn exposure.

While relatively few studies investigated Mn exposures with biomarkers and neurodevelopment outcomes in infants, those studies using prospective study designs provided compelling evidence of the adverse effect of $\mathrm{Mn}$. Biomakers of Mn using cord blood or serum provided a temporal association between fetal $\mathrm{Mn}$ exposures and later outcomes including cognitive and language development scores in 2 year olds [28], attention and nonverbal memory and hand skills in 3 year olds [43], and behavioral neurological development in newborns [57].

Measurement of Mn deposits in shed teeth provided insights more precise than those of cord blood or serum into the timing of early life exposures. While the CHAMACOS study is a large and comprehensive study of potential neurodevelopmental effects from pre-and postnatal dentin-Mn exposure in school-aged children [39, 45], the findings raise questions as the direction of the effects observed with higher levels pre- and postnatal $\mathrm{Mn}$ included both adverse effects with behavioral outcomes and positive effects with better memory abilities 
[39] inconsistent with other studies of school age children reporting higher Mn levels associated with poorer memory $[4,16,54]$ and cognitive outcomes $[15,16,31$, $32,35-37]$. These authors posit the inconsistent findings may be due to differences in the exposure matrix used to quantify Mn levels or Mn exposure pathways or possibly that the levels of $\mathrm{Mn}$ in their sample could be within the range at which $\mathrm{Mn}$ acts as a beneficial nutrient rather a than a neurotoxicant suggesting a need for additional research [39].

Based on the studies reviewed here, hair-Mn was the most frequently examined biomarker, and it was consistently associated with lower child IQ scores suggesting hair may be the most consistent and valid biomarker for $\mathrm{Mn}$ to date for children in population studies. While blood-Mn was associated with a range of neurodevelopmental outcomes, the findings across studies were inconsistent.

Bouchard and colleagues acknowledged the lack of consensus on an optimal biomarker of exposure to $\mathrm{Mn}$ and blood-Mn levels can vary widely in the short-term and likely does not reflect long-term exposure [32]. Oulhote et al. reported that blood and urine are poor measures of Mn exposure [47].

In contrast, hair-Mn is posited by these investigators as a more consistent and valid biomarker of Mn. Bouchard et al. reported that hair-Mn will reflect the metal uptake averaged over the duration of the follicle formation although the mechanism of Mn uptake into hair is not well understood [32]. Hair typically grows $1 \mathrm{~cm}$ per month thereby providing an exposure estimate of 1-6 months [15]. Lucchini et al.'s preliminary analysis of hair biomarkers of Mn suggests it may be a better measure of integrated exposure and body burden over the prolonged period of hair growth, relative to biomarkers of blood or urine $\mathrm{Mn}$, due to its rapid homeostatic control [33]. However, variability in hair-Mn concentrations may be related to various factors including difference in exposure, pharmacokinetics, hair pigmentation and issues of sample collection and cleaning [15]. Hair analysis for $\mathrm{Mn}$ requires rigorous cleaning procedures to minimize contribution of external $\mathrm{Mn}$ contamination without comprising endogenously incorporated $\mathrm{Mn}[33,60]$.

Interpretation of $\mathrm{Mn}$ levels in hair must be carefully evaluated because Mn levels may be higher in some hair types than others (i.e., in darker hair), and because dye, bleach or other topical treatment may either contaminate hair or effect $\mathrm{Mn}$ incorporation into its structure [61, 62], although topical hair treatment is less relevant for studies of children. Additionally, in a pilot study in progress we have found some infants lack sufficient hair to analyze.

The literature also lacks sufficient analyses of the connections between the environmental source, the internal dose and the associated neurodevelopmental and cognitive outcomes. Studies reported findings supporting the exposure-outcome relationship between Mn concentrations in water, hair and adverse outcomes in child neurodevelopment [32, 37, 47]. In contrast, investigators who collected data on well water-Mn, blood-Mn and neurological outcomes failed to demonstrate an association between $\mathrm{Mn}$ concentrations in water and blood $[18,29,30]$. However, a statistically significant and dosedependent association between water-Mn concentrations and IQ scores (Full Scale, Performance and Verbal) was reported [18]. This result is important as it provides strong evidence that ingestion of drinking water is a major source of environmental Mn potentially related to adverse neurodevelopment.

Few studies provided evidence of the association of environmental sources, biomarkers of $\mathrm{Mn}$ and neurodevelopment outcomes. Torres-Agustín et al. reported significantly higher $\mathrm{Mn}$ in blood and hair in an exposed (versus control) group with respiratory exposure to fine particulate matter of 2.5 microns or less in width, although only hair-Mn was significantly associated with poorer neurological outcomes [54]. This is important, though they did not report how increases in air Mn content affected Mn biomarker levels. However, Lucchini et al. reported evidence of both blood-Mn and hair-Mn being associated with increased tremor intensity in the dominant hand, and a borderline association between soil-Mn and tremor intensity. These authors report that the soil-Mn reflects past or cumulative exposures [33]. Future studies also need to quantify the association between environmental sources and selected biomarkers.

Finally, it is important that the continuum of exposure is carefully measured given the possibility of an inverted U-shaped association between Mn exposure and children's health, neurodevelopment and cognitive outcomes. Ultimately, if public health programs are to provide prevention guidance for specific exposure sources such as drinking water, PM10 and soil regarding over-exposure to $\mathrm{Mn}$, the threshold of beneficial Mn exposure must also be identified to ensure children receive the optimal benefit and the safe limit relative to their age and duration of exposure.

\section{Conclusion}

With evidence mounting for the negative impact of Mn on children, research is needed to address the gaps in the literature that would help elucidate safe levels of Mn exposure for fetuses, infants and children. There is a particular need for a consistent measurement approach to biomarkers of $\mathrm{Mn}$, as well as for environmental exposure sources and neurological outcomes, to make research findings comparable across studies. Additionally, feasibility issues are important when selecting biomarkers of exposure. The most promising Mn biomarker to date for the study of children 
is hair, but hair collection is not feasible for all infants and cleaning exogenous contamination of hair requires particular attention to evidence-based procedures. While cord blood appears an effective biomarker for measuring fetal exposure, it is logistically challenging and expensive to collect if study participants give birth at multiple hospitals. The use of teeth as a biomarker of $\mathrm{Mn}$ is intriguing, but it requires a minimum of 8 years from enrollment of pregnant women before children start to shed teeth that can be analyzed for Mn concentrations. The scientific and practical challenges of selecting the best biomarkers of $\mathrm{Mn}$ in children suggests the need for novel applications of additional biomarkers of chronic exposure to Mn. to help inform the science and ultimately determine public health prevention policies particularly for fetuses and infants given their heightened vulnerability to excessive Mn.

\section{Acknowledgements}

Not applicable.

\section{Funding}

This study was funded through the Consortium on Law and Values in Health, Environment and the Life Sciences, University of Minnesota. The Consortium was not involved in any phase of the research for or writing of this paper.

\section{Availability of data and materials}

Not applicable (i.e., this paper is a review of the literature).

\section{Authors' contributions}

DC conducted the original literature search, critically reviewed the human studies, drafted the paper and developed the tables. PM conceived of the paper, critically reviewed the human studies, revised drafts and supervised DC's work. RR drafted manuscript sections on the preclinical studies on the effects of excess Mn exposure on neurodevelopment and the pathways involved and reviewed all drafts of the paper. LH critically reviewed studies assessing Mn intake via diet, water and infant feeding practices and reviewed all drafts of the paper. MG helped conceptualize the paper and reviewed all drafts of the paper. IS helped conceptualize the paper, reviewed all drafts of the paper and oversaw review of the scientific content. All authors read and approved the final manuscript.

\footnotetext{
Authors' information

${ }^{1}$ DC is a student at the School of Medicine, University of Minnesota.

${ }^{2}$ PM is the Bond Professor of Environmental and Occupational Health Policy in the School of Public Health, University of Minnesota.

${ }^{3}$ RR is an Associate Professor in Pediatrics, at the School of Medicine and a clinical neonatologist at the Neonatal Intensive Care Unit of the University of Minnesota Masonic Children's Hospital.

${ }^{4} \mathrm{LH}$ is a Professor and Director for the Nutrition Coordinating Center in the Division of Epidemiology and Community Health, School of Public Health, University of Minnesota.

${ }^{5} \mathrm{MG}$ is the Martin Lenz Harrison Land Grant Chair, Professor in Pediatrics and Institute of Child Development, Director of the Division of Neonatology and Director of the Center for Neurobehavioral Development in the School of Medicine, University of Minnesota.

${ }^{6}$ IS an Associate Professor in the Division of Environmental Sciences, School of Public Health and the Masonic Cancer Center at the University of Minnesota.
}

\section{Competing interests}

The authors declare they have no competing interests.

\section{Consent for publication}

Not Applicable.

\section{Ethics approval and consent to participate}

Not Applicable.

\section{Author details}

${ }^{1}$ Medical School, University of Minnesota, 420 Delaware Street SE, Minneapolis, MN 55455, USA. ${ }^{2}$ Division of Environmental Health Sciences, School of Public Health, University of Minnesota, Mayo Building, MMC 807, 420 Delaware St. SE, Minneapolis, MN 55455, USA. ${ }^{3}$ Neonatology Division, University of Minnesota, Mayo Mail Code 391, 420 Delaware St. SE, Minneapolis, MN 55455, USA. ${ }^{4}$ School of Public Health, University of Minnesota, 300 West Bank Office Building 1300 S 2nd St, Minneapolis, MN 55454, USA. ${ }^{5}$ Martin Lenz Harrison Land Grant Chair, Pediatrics and the Institute of Child Development, Center for Neurobehavioral Development, University of Minnesota, 717 Delaware Street SE, Ste. 333, Minneapolis, MN 55414, USA. ${ }^{6}$ Division of Environmental Health Sciences, School of Public Health, University of Minnesota, 420 Delaware St SE, MMC 807, Minneapolis, MN 55454, USA

Received: 24 December 2015 Accepted: 23 August 2016

Published online: 30 August 2016

\section{References}

1. Polanczyk G, de Lima MS, Horta BL, Biederman J, Rohde LA. The worldwide prevalence of ADHD: a systematic review and metaregression analysis. Am J Psychiatry. 2007;164(6):942-8

2. Bloom B, Jones LI, Freeman G. Summary health statistics for U.S. children: National Health Interview Survey, 2012. Vital Health Stat. 2013;10(258):1-81.

3. Akinbami $\mathrm{LJ}$, Liu X, Pastor PN, Reuben CA. Attention deficit hyperactivity disorder among children aged 5-17 years in the United States, 1998-2009. NCHS Data Brief. 2011;70:1-8.

4. Grandjean P, Landrigan PJ. Neurobehavioral effects of developmental toxicity. Lancet Neurol. 2014;13(3):330-8.

5. Fechter LD. Distribution of manganese in development. Neurotoxicology. 1999;20(2-3):197-201.

6. Erikson KM, Thompson K, Aschner J, Aschner M. Manganese neurotoxicity: a focus on the neonate. Pharmacol Ther. 2007;113(2):369-77.

7. Dorman DC, Struve MF, Vitarella D, Byerly FL, Goetz J, Miller R. Neurotoxicity of manganese chloride in neonatal and adult $C D$ rats following subchronic (21-day) high-dose oral exposure. J Appl Toxicol. 2000;20(3):179-87.

8. Aschner M. Manganese: brain transport and emerging research needs. Environ Health Perspect. 2000;108 Suppl 3:429-32.

9. Hernández RB, Farina M, Espósito BP, Souza-Pinto NC, Barbosa Jr F, Suñol C. Mechanisms of manganese-induced neurotoxicity in primary neuronal cultures: the role of manganese speciation and cell type. Toxicol Sci. 2011;124(2):414-23.

10. Kern $\mathrm{CH}$, Stanwood GD, Smith DR. Preweaning manganese exposure causes hyperactivity, disinhibition, and spatial learning and memory deficits associated with altered dopamine receptor and transporter levels. Synapse. 2010:64(5):363-78.

11. Betharia S, Maher TJ. Neurobehavioral effects of lead and manganese individually and in combination in developmentally exposed rats. Neurotoxicology. 2012;33(5):1117-27.

12. Erikson KM, Syversen T, Aschner JL, Aschner M. Interactions between excessive manganese exposures and dietary iron-deficiency in neurodegeneration. Environ Toxicol Pharmacol. 2005;19(3):415-21.

13. Aschner M, Guilarte TR, Schneider JS, Zheng W. Manganese: recent advances in understanding its transport and neurotoxicity. Toxicol Appl Pharmacol. 2007;221(2):131-47.

14. Zoni S, Lucchini RG. Manganese exposure: cognitive, motor and behavioral effects on children: a review of recent findings. Curr Opin Pediatr. 2013; 25(2):255-60.

15. Haynes EN, Sucharew H, Kuhnell P, Alden J, Barnas M, Wright RO, et al. Manganese exposure and neurocognitive outcomes in rural school-age children: the communities actively researching exposure study (Ohio, USA). Environ Health Perspect. 2015;123(10):1066-71.

16. Wright RO, Amarasiriwardena C, Woolf $A D$, Jim R, Bellinger DC. Neuropsychological correlates of hair arsenic, manganese, and cadmium levels in school-age children residing near a hazardous waste site. Neurotoxicology. 2006;27(2):210-6.

17. Bouchard M, Laforest F, Vandelac L, Bellinger D, Mergler D. Hair manganese and hyperactive behaviors: pilot study of school-age children exposed through tap water. Environ Health Perspect. 2007;115(1):122-7. 
18. Wasserman GA, Liu X, Parvez F, Ahsan H, Levy D, Factor-Litvak P, et al. Water manganese exposure and children's intellectual function in Araihazar, Bangladesh. Environ Health Perspect. 2006;114(1):124-9.

19. Aschner $\mathrm{M}$. The transport of manganese across the blood-brain barrier. Neurotoxicology. 2006;27(3):311-4.

20. Dorman DC, Struve MF, Wong BA. Brain manganese concentrations in rats following manganese tetroxide inhalation are unaffected by dietary manganese intake. Neurotoxicology. 2002;23(2):185-95.

21. Schwartz R, Apgar BJ, Wien EM. Apparent absorption and retention of Ca, Cu, Mg, Mn, and Zn from a diet containing bran. Am J Clin Nutr. 1986;43(3):444-55.

22. Dörner K, Dziadzka S, Höhn A, Sievers E, Oldigs HD, Schulz-Lell G, et al. Longitudinal manganese and copper balances in young infants and preterm infants fed on breast-milk and adapted cow's milk formulas. $\mathrm{Br}$ J Nutr. 1989;61(3):559-72.

23. World Health Organization (WHO). Guidelines for drinking-water quality. 4th ed. Geneva: WHO; 2011. p. 177-226

24. Frisbie SH, Mitchell EJ, Dustin H, Maynard DM, Sarkar B. World Health Organization discontinues its drinking-water guideline for manganese. Environ Health Perspect. 2012;120(6):775-8.

25. United States Environmental Protection Agency (EPA). Drinking Water Health Advisory for Manganese. (EPA-822-R-04-003) 2004. http://www.epa. gov/safewater/Accessed 12 Dec 2015.

26. Kim Y, Kim BN, Hong YC, Shin MS, Yoo HJ, Kim JW, et al. Co-exposure to environmental lead and manganese affects the intelligence of school-aged children. Neurotoxicology. 2009;30(4):564-71.

27. Claus Henn B, Schnaas L, Ettinger AS, Schwartz J, Lamadrid-Figueroa H, Hernández-Avila M, et al. Associations of early childhood manganese and lead coexposure with neurodevelopment. Environ Health Perspect. 2012; 120(1):126-31

28. Lin CC, Chen YC, Su FC, Lin CM, Liao HF, Hwang YH, et al. In utero exposure to environmental lead and manganese and neurodevelopment at 2 years of age. Environ Res. 2013;123:52-7.

29. Khan K, Factor-Litvak P, Wasserman GA, Liu X, Ahmed E, Parvez F, et al. Manganese exposure from drinking water and children's classroom behavior in Bangladesh. Environ Health Perspect. 2011;119(10):1501-6.

30. Wasserman GA, Liu X, Parvez F, Factor-Litvak P, Ahsan H, Levy D, et al. Arsenic and manganese exposure and children's intellectual function. Neurotoxicology. 2011;32(4):450-7.

31. Riojas-Rodríguez H, Solís-Vivanco R, Schilmann A, Montes S, Rodríguez S, Ríos $C$, et al. Intellectual function in Mexican children living in a mining area and environmentally exposed to manganese. Environ Health Perspect. 2010; 118(10):1465-70.

32. Bouchard MF, Sauvé S, Barbeau B, Legrand M, Brodeur MÈ, Bouffard T, et al. Intellectual impairment in school-age children exposed to manganese from drinking water. Environ Health Perspect. 2011;119(1):138-43.

33. Lucchini RG, Guazzetti S, Zoni S, Donna F, Peter S, Zacco A, et al. Tremor, olfactory and motor changes in Italian adolescents exposed to historical ferro-manganese emission. Neurotoxicology. 2012;33(4):687-96.

34. Collipp PJ, Chen SY, Maitinsky S. Manganese in infant formulas and learning disability. Ann Nutr Metab. 1983;27(6):488-94.

35. Menezes-Filho JA, Novaes Cde O, Moreira JC, Sarcinelli PN, Mergler D. Elevated manganese and cognitive performance in school-aged children and their mothers. Environ Res. 2011;111(1):156-63.

36. Carvalho CF, Menezes-Filho JA, de Matos VP, Bessa JR, Coelho-Santos J, Viana GF, et al. Elevated airborne manganese and low executive function in school-aged children in Brazil. Neurotoxicology. 2014;45:301-8.

37. do Nascimento SN, Barth A, Göethel G, Baierle M, Charão MF, Brucker N, et al. Cognitive deficits and ALA-D-inhibition in children exposed to multiple metals. Environ Res. 2015;136:387-95.

38. Sun $H$, Chen $W$, Wang $D$, Jin $Y$, Chen $X, X u Y$, et al. Inverse association between intelligence quotient and urinary retinol binding protein in Chinese school-age children with low blood lead levels: results from a cross-sectional investigation. Chemosphere. 2015;128:155-60.

39. Mora AM, Arora M, Harley KG, Kogut K, Parra K, Hernández-Bonilla D, et al. Prenatal and postnatal manganese teeth levels and neurodevelopment at 7 , 9, and 10.5 years in the CHAMACOS cohort. Environ Int. 2015;84:39-54.

40. Bhang SY, Cho SC, Kim JW, Hong YC, Shin MS, Yoo HJ, et al. Relationship between blood manganese levels and children's attention, cognition, behavior, and academic performance-a nationwide cross-sectional study. Environ Res. 2013;126:9-16.
41. Lucchini RG, Zoni S, Guazzetti S, Bontempi E, Micheletti S, Broberg K, et al. Inverse association of intellectual function with very low blood lead but not with manganese exposure in Italian adolescents. Environ Res. 2012;118:65-71.

42. Chung SE, Cheong HK, Ha EH, Kim BN, Ha M, Kim Y, et al. Maternal blood manganese and early neurodevelopment: The Mothers and Children's Environmental Health (MOCEH) Study. Environ Health Perspect. 2015;123(7):717-22.

43. Takser L, Mergler D, Hellier G, Sahuquillo J, Huel G. Manganese, monoamine metabolite levels at birth, and child psychomotor development. Neurotoxicology. 2003;24(4-5):667-74.

44. Claus Henn B, Ettinger AS, Schwartz J, Téllez-Rojo MM, Lamadrid-Fiqueroa H, Hernández-Avila M, et al. Early postnatal blood manganese levels and children's neurodevelopment. Epidemiology. 2010;21(4):433-9.

45. Gunier RB, Arora M, Jerrett M, Bradman A, Harley KG, Mora AM, et al. Manganese in teeth and neurodevelopment in young Mexican-American children. Environ Res. 2015;142:688-95.

46. Rink SM, Ardoino G, Queirolo El, Cicariello D, Mañay N, Kordas K. Associations between hair manganese levels and cognitive, language, and motor development in preschool children from Montevideo, Uruguay. Arch Environ Occup Health. 2014;69(1):46-54.

47. Oulhote Y, Mergler D, Barbeau B, Bellinger DC, Bouffard T, Brodeur MË, et al. Neurobehavioral function in school-age children exposed to manganese in drinking water. Environ Health Perspect. 2014;122(12):1343-50.

48. Hernández-Bonilla D, Schilmann A, Montes S, Rodríguez-Agudelo Y, Rodríguez-Dozal S, Solís-Vivanco R, et al. Environmental exposure to manganese and motor function of children in Mexico. Neurotoxicology. 2011;32(5):615-21.

49. Parvez F, Wasserman GA, Factor-Litvak P, Liu X, Slavkovich V, Siddique AB, et al. Arsenic exposure and motor function among children in Bangladesh. Environ Health Perspect. 2011;119(11):1665-70.

50. Ode A, Rylander L, Gustafsson P, Lundh T, Källén K, Olofsson P, et al. Manganese and selenium concentrations in umbilical cord serum and attention deficit hyperactivity disorder in childhood. Environ Res. 2015;137:373-81.

51. Shin DW, Kim EJ, Lim SW, Shin YC, Oh KS, Kim EJ. Association of hair manganese level with symptoms in attention-deficit/hyperactivity disorder. Psychiatry Investig. 2015;12(1):66-72.

52. Ericson JE, Crinella FM, Clarke-Stewart KA, Allhusen VD, Chan T, Robertson RT. Prenatal manganese levels linked to childhood behavioral disinhibition. Neurotoxicol Teratol. 2007;29(2):181-7.

53. Menezes-Filho JA, de Carvalho-Vivas CF, Viana GF, Ferreira JR, Nunes LS, Mergler D, et al. Elevated manganese exposure and school-aged children's behavior: a gender-stratified analysis. Neurotoxicology. 2014;45:293-300.

54. Torres-Agustín R, Rodríguez-Agudelo Y, Schilmann A, Solís-Vivanco R, Montes S, Riojas-Rodríguez $\mathrm{H}$, et al. Effect of environmental manganese exposure on verbal learning and memory in Mexican children. Environ Res. 2013;121:39-44.

55. Wechsler D. Manual for the WISC-III. San Antonio: Psychological Corporation; 1991.

56. Bayley N. Bayley Scales of Infant Development. San Antonio: Psychological Corporation; 1993.

57. Yang X, Bao Y, Fu H, Li L, Ren T, Yu X. Selenium protects neonates against neurotoxicity from prenatal exposure to manganese. PLoS One. 2014;9(1):e86611.

58. Khan K, Wasserman GA, Liu X, Ahmed E, Parvez F, Slavkovich V, et al. Manganese exposure from drinking water and children's academic achievement. Neurotoxicology. 2012;33(1):91-7.

59. lannilli E, Gasparotti R, Hummel T, Zoni S, Benedetti C, Fedrighi C, et al. Effects of manganese exposure on olfactory functions in teenagers: a pilot study. PLoS One. 2016;11(1):e0144783.

60. Eastman RR, Jursa TP, Benedetti C, Lucchini RG, Smith DR. Hair as a biomarker of environmental manganese exposure. Environ Sci Technol. 2013;47(3):1629-37.

61. Aschner M, Erikson KM, Dorman DC. Manganese dosimetry: species differences and implications for neurotoxicity. Crit Rev Toxicol. 2005;35(1):1-32.

62. Barlow PJ. A pilot study on the metal levels in the hair of hyperactive children. Med Hypotheses. 1983;11(3):309-18. 